Hydrol. Earth Syst. Sci. Discuss., doi:10.5194/hess-2016-410, 2016

Manuscript under review for journal Hydrol. Earth Syst. Sci.

Published: 30 August 2016

(c) Author(s) 2016. CC-BY 3.0 License.

\title{
Application of global models and satellite data for smaller-scale groundwater recharge studies
}

\author{
Rogier Westerhoff ${ }^{1,2,3}$, Paul White ${ }^{1}$, and Zara Rawlinson ${ }^{2}$ \\ ${ }^{1}$ GNS Science, New Zealand \\ ${ }^{2}$ Deltares, The Netherlands \\ ${ }^{3}$ Waikato University, New Zealand \\ Correspondence to: R.S. Westerhoff (rogier.westerhoff@ deltares.nl)
}




\begin{abstract}
Large-scale models and satellite data are increasingly used to characterise groundwater and its recharge at the global scale. Although these models have the potential to fill in data gaps and solve trans-boundary issues, they are often neglected in smaller-scale studies, since data are often coarse or uncertain. Large-scale models and satellite data could play a more important role in smaller-scale (i.e., national or regional) studies, if they could be adjusted to fit that scale. In New Zealand, large-scale models and satellite data are not used for groundwater recharge estimation at the national scale, since regional councils (i.e., the water managers) have varying water policy and models are calibrated at the local scale. Also, some regions have many localised ground observations (but poor record coverage), whereas others are data-sparse. Therefore, estimation of recharge is inconsistent at the national scale.
\end{abstract}

This paper presents an approach to apply large-scale, global, models and satellite data to estimate rainfall recharge at the national to regional scale across New Zealand. We present a model, NGRM, that is largely inspired by the global-scale WaterGAP recharge model, but is improved and adjusted using national data. The NGRM model uses MODIS-derived ET and vegetation satellite data, and the available nation-wide datasets on rainfall, elevation, soil and geology. A valuable addition to the recharge estimation is the model uncertainty estimate, based on variance, covariance and sensitivity of all input data components in the model environment.

This research shows that, with minor model adjustments and use of improved input data, largescale models and satellite data can be used to derive rainfall recharge estimates, including their uncertainty, at the smaller scale, i.e., national and regional scale of New Zealand. The estimated New Zealand recharge of the NGRM model compare well to most local and regional lysimeter data and recharge models. The NGRM is therefore assumed to be capable to fill in gaps in data-sparse areas and to create more consistency between datasets from different regions, i.e., to solve trans-boundary issues. This research also shows that smaller-scale recharge studies in New Zealand should include larger boundaries than only a (sub-)aquifer, and preferably the whole catchment. This research points out the need for improved collaboration on the international to national to regional levels to further merge large-scale (global) models to smaller (i.e., national or regional) scales. Future research topics should, collaboratively, focus on: improvement of rainfall-runoff and snowmelt methods; inclusion of river recharge; further improvement of input data (rainfall, evapotranspiration, soil and geology); and the impact of recharge uncertainty in mountainous and irrigated areas.

\title{
1 Introduction
}

Large-scale hydrological models are increasingly used to characterise groundwater at the global scale (e.g., Gleeson et al., 2011; Fan et al., 2013), its fluxes (e.g., Döll and Fiedler, 2008; Beck et al., 2013) and its depletion (Wada et al., 2010). Furthermore, satellite data have been shown to be important for global-scale assessments of important water cycle variables, such as rainfall (GPM: 
Hou et al., 2014) and evapotranspiration (Miralles et al., 2011; Mu et al., 2011). The outlook of more climate extremes of droughts (Pozzi et al., 2013) and floods (Ward et al., 2015), will only make such large-scale models and datasets more important.

The utility of large-scale data sets can be increased by assessing methods to increase the spatial resolution, and thus national and regional applicability of such models. Large-scale models and satellite data are not often directly used for the smaller, e.g., national or regional, scale. That is mostly because the input data (e.g., meteo, terrain, soil, etc) for those large-scale models are, viewed from a national or regional perspective, relatively coarse and uncertain. For example, global ET data of the MOD16 product (Mu et al., 2011) uses a global input of meteorological data of NASA's Global Modeling and Assimilation Office (GMAO) of $1^{\circ}$ by $1.25^{\circ}$ of latitude and longitude resolution. These meteo data might be too coarse to cover diversity of some climates, such as occurring in countries like New Zealand, where rainfall can differ from approximately 0.5 to 10 metres over short distances, and evapotranspiration is highly variant over the nation (Figure 1a,b). The global WaterGAP recharge model of Döll and Fiedler (2008) uses input data of terrain, soil, geology from global databases, whereas countries such as New Zealand have more and often better input data (Figure 1c-f).

If large-scale models or satellite data were given local input data, or were adjusted to fit the local scale, they would have the potential to create consistency in areas with large data gaps or trans-boundary data differences. That is mostly because the large scale covers entire nations and continents. Trans-boundary issues occur, because neighbouring areas have different policy on water (e.g., its allocation). On either side of those boundaries different data standards and data formats may apply, model equations are often different, or the density of ground observation varies. Transboundary issues are not only occurring between countries. In New Zealand, regional councils are responsible for policy on water allocation. Groundwater recharge is often key input to set allocation limits and national guideline limits for groundwater allocation with respect to recharge exists (Ministry for the Environment, 2013, 2008), but policy and the subsequent recharge models and data used are managed at a regional scale. Therefore, development of a high-quality national assessment of groundwater and its recharge is challenging, given the inconsistency of recharge models and their input data (e.g., ground-observed or geological). Up to this day, New Zealand does not have this consistent nation-wide characterisation of groundwater recharge. The lack of such a nation-wide approach hinders further scientific advances in national hydrological modelling. For example, the New Zealand national surface water model (Topnet: Bandaragoda et al., 2004) could benefit from better information of groundwater fluxes, such as recharge. Large-scale models and satellite data, if improved for the smaller scale, then also have the potential to be used nationally and regionally to interpolate in data-sparse areas and to resolve trans-boundary inconsistencies.

Using a national approach in New Zealand might also improve understanding of uncertainty. As most models are calibrated in their local environment, not much is known about their uncertainty, 
especially near or beyond the boundaries of study areas, which are often only a sub-region and not a whole catchment. Application of multiple local models in one area also shows inconsistency. For example, the impact of rainfall recharge uncertainty was demonstrated by White et al. (2003), who used three rainfall recharge models for the Central Plains of Canterbury, New Zealand. They showed that estimated groundwater use as a percentage of rainfall recharge was highly model-dependent, and because of that dependency varied in between $63 \%$ and $80 \%$ in a relatively dry year. However, uncertainty has not typically been assessed by sub-regional models in New Zealand. Uncertainties can either be caused by the different model equations or by difference in input data. Most recharge models are some form of soil water balance Rushton et al. (2006); Westenbroek et al. (2010); White et al. (2003), and only show difference in the derivation of actual ET, or the assumed rainfall-runoff ratios. A regional study in New Zealand by Rawlinson et al. (2015) showed that the difference in three recharge models was most likely caused by the inconsistency of model input data and not by the differences in model equations. Development of a large-scale model that estimates model uncertainty and uses the same input data for the nation, is thus beneficial, even at the local scale.

This study describes the use of a national groundwater recharge model that is inspired by the global-scale WaterGap recharge model of Döll and Fiedler (2008) and uses MODIS satellite data of ET (Mu et al., 2011) and vegetation (Samanta et al., 2011). The aim of this research is to show that, can be used to derive rainfall recharge estimates, including their uncertainty, on the national scale of New Zealand, or smaller.

\section{Method}

The model in this study is called the 'National Groundwater Recharge Model' (NGRM). We present the NGRM in three stages. First, a general description of the method is given. Second, input data are elucidated, including a description of pre-processing steps. Third, detailed methodology, including uncertainty estimation, is described.

\subsection{General description}

The NGRM has a $1 \mathrm{~km}$ model grid that covers most of New Zealand (Figure 1). The model calculates rainfall recharge to groundwater in monthly time steps, currently covering the period of January 2000 to December 2014. The NGRM uses a simple soil water balance, i.e., it calculates a mass balance between vertical water inflow and outflow in a simple representation of the soil (i.e., one layer), and it is assumed that any surplus water in the soil layer either drains to groundwater or goes to runoff. Other common soil water balance models are the groundwater recharge module in WaterGAP (Döll and Fiedler, 2008), USGS-SWB (Westenbroek et al., 2010), Rushton (Rushton et al., 2006). The NGRM consists of a newly developed method and code, but is largely inspired by the approach 
of the WaterGAP model, that calculates an initial recharge and then uses several correction factors to estimate true recharge, i.e., for slope, soil, geology and more. The strengths of the WaterGAP model are, in our opinion: it is a simple but rigorous method; it is a well described and accepted method; and it includes a deeper 'geology' layer. The input data used for the NGRM model include satellite data of ET and vegetation, and New Zealand national datasets of soil, geology, elevation, and precipitation.

The NGRM is uncalibrated. However, case study comparisons described within this article have been used to improve the nation-wide model equations such that the model is considered to provide suitable estimates in these case studies.

\subsection{Input data and processing}

The rainfall recharge model uses input data on precipitation, evapotranspiration, vegetation, topography, soil parameters, and geology. These are summarised below. All data were re-gridded to the monthly $1 \mathrm{~km}$ x $1 \mathrm{~km}$ model cells, which are projected to the national New Zealand Transverse Mercator (NZTM) grid. This was done by averaging (if the time step or grid resolution of the original input data was smaller) or by its nearest value (if the grid resolution of the original input data was larger).

\subsubsection{Precipitation}

Daily precipitation data from 1972 to the present day are available for New Zealand in a regular grid $\left(0.05^{\circ}\right.$ of latitude and longitude, or approximately $\left.5 \mathrm{~km}\right)$ from the Virtual Climate Station (VCS) network (Tait, 2014). These data are described by Tait et al. (2006). Only data covering the period 1-Jan-2000 to 31-Dec-2013 were used in this study (mean annual values are shown in Figure 1a).

\subsubsection{Evapotranspiration}

The MOD16 algorithm uses satellite data from NASA's MODerate resolution Imaging Spectrora-

diometer (MODIS) sensor. The satellite-derived parameters embedded in the MOD16 dataset are land cover, albedo, leaf area index (LAI), fraction of absorbed photosynthetically active radiation (FPAR), and enhanced vegetation index (EVI). Temperature, radiation, air humidity and pressure data are derived from the daily global meteorological reanalysis data set from NASA's Global Modeling and Assimilation Office (GMAO). The MOD16 algorithm, described in Mu et al. (2011), uses the Penman-Monteith approach to calculate evapotranspiration. The spatial resolution of the MOD16 cells is approximately $1 \mathrm{~km} \times 1 \mathrm{~km}$. MOD16 PET and MOD16 AET data are available online in HDF (Hierarchical Data Format) files in 8-daily, monthly, and yearly intervals (NTSG, 2013). Monthly MOD16 PET data were tested in the New Zealand setting by Westerhoff (2015), who also derived a MOD16 Penman PET conversion and uncertainty estimate for these data (since Penman 
PET is the national standard). Westerhoff (2015) furthermore suggests that MOD16 AET could be used in New Zealand studies, since: they seem to fit expected values and patterns in large parts of New Zealand; and the data already take into account vegetation characteristics. The above described monthly MOD16 Penman PET and MOD16 AET, covering the period January 2000 to December 2013, were used in this study (mean annual AET is shown in Figure 1b). They are called PET and AET onwards.

\subsubsection{Terrain model}

The Geographx New Zealand DEM 2.1 (Geographx, 2012) is a national digital elevation model (Figure 1c) on an $8 \mathrm{~m} \times 8 \mathrm{~m}$ grid that was derived from a combination of New Zealand-based topographic data from Land Information New Zealand and data from the satellite-derived Shuttle Radar Topography Mission (SRTM: USGS, 2006).

\subsubsection{Geology}

Geology is defined as the subsurface underlying the soil. The geology of the shallow subsurface, i.e. up to approximately $10 \mathrm{~m}$ depth, is described by the 1:250,000 geological map of New Zealand (QMAP: GNS Science, 2012). This digital map, a GIS polygon file, includes several polygon attributes, of which main rock type, secondary rock type, and age were used in this study. The main rock type and secondary rock type were interpreted to hydrolithological classes and intrinsic permeability $\kappa\left[\mathrm{m}^{2}\right]$. The estimation of $\kappa$ was based on a classification method described by Gleeson et al. (2011), who derive $\kappa$ and standard deviation for 7 main hydrolithological classes, using the information from Freeze and Cherry (1979), their table 2.2, and calibration results of a multitude of global and local hydrological models. Additionally, this classification was put in the New Zealand context by with 3 additional hydrolithological classes. These classes, each with a median and standard deviation value of $\kappa$ (Table 1), are used in this research. All QMAP different rock type attributes could be summarised to 183 'dictionary' values of rock type, which were then interpreted to permeabilities with a look-up table approach. Two examples are given: (1) sandstone, greenstone were interpreted as 'coarse-grained sedimentary' and were given a permeability $(\log \kappa)$ of -12.5 , with an uncertainty (standard deviation $1 \sigma$ ) of 0.9 ; (2) limestone and shell beds were interpreted as carbonate and were given a permeability of -11.8 , with an uncertainty of 1.5 .

Permeabilities of main rock type and secondary rock type were combined by a weighting average, in which the $\kappa$ value of main rock type was weighted two times heavier than the secondary rock type.

It was assumed that vertical $\mathrm{K}$ is equal to horizontal saturated hydraulic conductivity. For the conversion of intrinsic permeability to hydraulic conductivity $\mathrm{K}$ [m/day] we used Eq. 1:

$K=86400 \frac{\kappa \rho g}{\mu}$, 
following (Freeze and Cherry, 1979, their Eq. 2.28), where:

$-\mu$ is the dynamic viscosity of freshwater at $13^{\circ} \mathrm{C}\left(=1.2155 \times 10^{3} \mathrm{~kg} / \mathrm{m} \mathrm{s}\right)$;

- $\rho$ is the density of fresh water $\left(=1000 \mathrm{~kg} / \mathrm{m}^{3}\right)$;

- $g$ is the gravitational constant $\left(=9.90 \mathrm{~m}^{2} / \mathrm{s}\right)$.

The estimation of decrease of K over age is not straightforward. For example, Akbar et al. (1995) point out, for carbonates, that the relation between porosity and age is influenced by many factors such as diagenesis, pressure, temperature, and erosion. We chose to include a correction factor with age to exclude old (hard)rock, to show a more realistic distribution of aquifers throughout New Zealand. The correction factor is based on an exponential decrease of hydraulic conductivity with age (Eq. 2):

$f_{T}=e^{-T / \alpha}$

where $T$ is the geological age [Ma] and $\alpha$ a constant that controls the decrease rate. The value of $\alpha$ was (arbitrarily) set to 40 , so that $f_{T}$ was close to 1 for Quaternary rock types (i.e., younger than 1.8 Ma).

A national map of estimated hydraulic conductivity as used for the NGRM is shown in Figure 1d.

\subsubsection{Soil}

Soil permeability is the rate that water moves through saturated soil. New Zealand-wide soil permeability data are available from the Fundamental Soil Layer (FSL) layer in the Land Resource Information Systems (LRIS) portal Landcare Research (2014) as an ArcGIS shapefile with qualitative classes after Newsome et al. (2008) (e.g., 'Slow', 'Rapid over moderate', see Table 2). The FSL was chosen because it is the only dataset that covers the entire nation. Soil permeability was interpreted from the original soil qualitative classes to relative soil permeability ratio $f_{\text {soil }}$ in between 0 and 1 (Table 2). Soil permeability ratios are shown in Figure 1e.

Profile of Available Water (PAW) is the difference between field capacity and permanent wilting point. PAW is a soil property defining the total amount of available water that can be held by a soil profile (Smith and Mullins, 2001). PAW data are available from the LRIS portal as an ArcGIS shapefile, with each soil class having a minimum and maximum value (Table 3). Modal values were calculated according to Newsome et al. (2008) and shown in Figure 1f. For areas where PAW was unknown, the mean of all PAW modal values was assumed.

\subsubsection{Leaf Area Index}

Leaf Area Index (LAI) is derived from surface reflectance in the red and near-infrared bands mea- 
Hydrol. Earth Syst. Sci. Discuss., doi:10.5194/hess-2016-410, 2016

in broadleaf canopies, and one half the total surface area per unit ground area in needle leaf canopies (Samanta et al., 2011). Monthly data from January 2001 and December 2013 of LAI were obtained from the MODIS C5 LAI/FPAR $1 \mathrm{~km}$ grid product from Park (2015), a by-product which is the extracted best quality of standard C5 LAI/FPAR based on MOD15A2 and MOD13A2 quality flags. LAI values are classified in between 0 (minimum $\mathrm{LAI}=$ no vegetation) and 10 (maximum LAI). A compilation of these data, as monthly means, is plotted in Figure 2.

Additional pre-processing was applied to both monthly precipitation to correct for canopy interception (Ic). Based upon studies of Gerrits (2010), who assessed and measured $I c$ for a range of vegetation types, and Zhou et al. (2006), who defined $I c$ as a function of precipitation and LAI, we define $I c$ as $\mathrm{Eq} 3$ :

$I c=\frac{P * L A I}{3 E 03}$

so that a conservative estimate of $2 \%$ of rainfall will be intercepted by the canopy at maximum LAI (approximately 6). The interception was subtracted from the precipitation dataset. It was assumed that the satellite-measured MOD16 AET already embeds the evaporation of the intercepted water and therefore $I c$ was not added to AET.

\subsubsection{Snow}

The monthly precipitation data, after correction for interception, were corrected for the precipitation being snow rather than rain. A very simple assumption was made: if the average monthly temperature (from the VCS data) is lower than 0, all precipitation is assumed snow. If the average monthly temperature is between 0 and 4,30\% of the precipitation is assumed snow. The implications of this simplicity are further explained in the discussion.

\subsection{Rainfall recharge model equation}

In monthly time steps, rainfall recharge RRECH (in $\mathrm{mm}$ ) was calculated for time step i as:

$R R E C H_{i}=\left[R_{i} f_{\text {slope }}-A E T_{i}-S_{i-1}\right] f_{\text {soil }} f_{\text {geol }} \quad ; R R E C H_{i}>0$,

where:

$R_{i}$ is surface rainfall (in mm, after correction for interception and snow);

$f_{\text {slope }}$ is a correction factor for rainfall runoff due to slope [0 to 1];

$A E T$ is actual evapotranspiration (in $\mathrm{mm}$ );

$S$ is soil storage $(\mathrm{mm})$; 
If $R R E C H_{i}<0$ (Eq. 4), then $R R E C H_{i}$ is set to zero and the resulting storage deficit $S_{i}<S_{i-1}$ is used for the calculation of $R R E C H_{i+1}$.

The slope correction factor $f_{\text {slope }}$ was calculated from the terrain model. After calculating a slope $\alpha$ (in degrees) from the terrain model, this was then used to calculate an initial runoff of the rainfall due to slope:

$f_{\text {slope }}=1-\operatorname{erf}(2 \alpha)$

where the error function (erf) fits the empirical slope - runoff relation used by Döll and Fiedler (2008). The NGRM model prefers to use the simple relation to terrain slope, instead of other alternatives that use a relation between rainfall intensity and soil type (e.g., Rushton et al., 2006; Westenbroek et al., 2010). Also, the NGRM model prefers the $f_{\text {slope }}$ to directly affect rainfall, and not affect $A E T$ and $S$, as in Döll and Fiedler (2008). Possible model limitations arising because of this simplification are explained in the discussion.

The initial soil storage $S_{\text {init }}$ for the first time step (January 2000) was estimated as a function of the modal values of PAW for a vegetated surface:

$S_{\text {init }}=0.67 P A W$

This initial soil storage stems from the 'water holding capacity' of a soil with vegetation (i.e., roots) and is described by White et al. (2003) and Scott (2004) for a grass surface. Using this initial storage means the model has an unknown error in soil storage in the first few months of the model runs (because not all soils were at their driest in January 2000). It is assumed that this unknown error is resolved after six months (July 2000), when most soils are at their wettest.

The factor $f_{\text {soil }}$ represents the impedance to recharge from soil and is given by the soil permeability ratio (Table 2). For $f_{\text {soil }}$, it was assumed that soils lower than a value of 0.15 (equivalent to a soil permeability of less than $4 \mathrm{~mm} / \mathrm{hr}$, Newsome et al., 2008) reject $75 \%$ of the rainfall recharge to surface runoff; all other soils accept all recharge. The model assumes an isotropic permeability, i.e., that vertical and lateral flow are equal, and that any rejected recharge will add to runoff within the same model cell.

The geology factor $f_{\text {geol }}$ represents the impedance to recharge from geology. Hydraulic conductivity was assumed to only play a limiting role if its value was less than the rainfall recharge. In practice, this means that only very impermeable geology (e.g., clay, basement rock, mudstone) would limit rainfall recharge. The factor $f_{\text {geol }}$ was then calculated as the ratio (in between 0 and 1 ) of potential rainfall recharge and hydraulic conductivity. 
Hydrol. Earth Syst. Sci. Discuss., doi:10.5194/hess-2016-410, 2016

\subsection{Uncertainty of rainfall recharge}

The uncertainty of the NGRM model was calculated by error propagation, i.e., propagating the variance and covariance of all input components, including their model sensitivity, through the rainfall recharge equation (Eq. 4), after Tellinghuisen (2001):

$\sigma_{f}^{2}=\mathbf{g}^{T} \mathbf{V g}$

where $\sigma_{f}^{2}$ is the variance of a function $f$, which has $n=1: N$ input components; $\mathbf{V}$ is the variance-covariance matrix of all input components; $g$ is a vector of input component $\partial f / \partial n_{i}$; and $\mathbf{g}^{T}$ is the transpose of $\mathbf{g}$. Considering Eq. 4 , the components of $\mathbf{g}$ are ( $R R E C H$ is denoted as $\Psi$ to spare length of the equations):

$$
\begin{array}{r}
\mathbf{g}=\left(\frac{\partial \Psi}{\partial R}, \frac{\partial \Psi}{\partial f_{\text {slope }}}, \frac{\partial \Psi}{\partial A E T}, \frac{\partial \Psi}{\partial S}, \frac{\partial \Psi}{\partial f_{\text {soilgeol }}}\right) \\
\frac{\partial \Psi}{\partial R}=f_{\text {slope }} f_{\text {soilgeol }} \\
\frac{\partial \Psi}{\partial f_{\text {slope }}}=R f_{\text {soilgeol }} \\
\frac{\partial \Psi}{\partial A E T}=-f_{\text {soilgeol }} \\
\frac{\partial \Psi}{\partial S}=-f_{\text {soilgeol }} \\
\frac{\partial \Psi}{\partial f_{\text {soilgeol }}}=R f_{\text {slope }}-A E T-S
\end{array}
$$

Where the components $f_{\text {soil }}$ and $f_{\text {geol }}$ were multiplied to one factor $f_{\text {soilgeol }}$ beforehand. The components of $\mathbf{V}$ are:

$285 \quad \mathbf{V}=\left[\begin{array}{ccccc}\sigma_{R}^{2} & \ldots & \ldots & \ldots & \ldots \\ \ldots & \sigma_{f_{\text {slope }}}^{2} & \ldots & \ldots & \ldots \\ \ldots & \ldots & \sigma_{A E T}^{2} & \ldots & \ldots \\ \ldots & \ldots & \ldots & \sigma_{S}^{2} & \ldots \\ \ldots & \ldots & \ldots & \ldots & \sigma_{f_{\text {soilgeol }}}^{2}\end{array}\right]$

The dots (i.e., '..') indicate covariances between the parameters. Covariance was calculated with a subset of 5\% of all (100,000 of approximately 267,000 pixels and 2 of 14 years) monthly time series of all input components ( $\mathrm{R}, f_{\text {slope }}$, AET, $\mathrm{S}, f_{\text {soil }}$ and $\left.f_{\text {geol }}\right)$. The uncertainty of the model input components were estimated, as values of the standard deviation $(1 \sigma)$, as follows:

- The uncertainty of rainfall per monthly time step was assumed 5\% in plain areas (with many rain gauges) to $15 \%$ in steep-sloped regions (without rain gauges). This is in line with earlier findings of maximum uncertainty of $15 \%$, after Tait et al. (2006); 
- The uncertainty in the estimation of $f_{\text {slope }}$ was assumed to be $10 \%$. This was assumed to be affected by general inaccuracy of terrain models (e.g., Westerhoff et al., 2013) and averaging of the terrain model to the model grid;

- The uncertainty in daily Penman PET in New Zealand can be 10 - 40\% (Westerhoff, 2015) and is a function of the PET value. Daily values of this uncertainty function were compiled to monthly and mean annual values. For this study, it was assumed that the uncertainty of AET decreases with the AET/PET ratio;

- Uncertainty in storage was assumed to be a function of PAW. A Gaussian distribution was assumed between minimum and maximum values of PAW, making the $1 \sigma$ value $16 \%$ of the range;

- The standard deviation of the $f_{\text {soil }}$ values was assumed to be $10 \%$, except for the 'Slow' and 'Rapid' classes, where they are chosen as $5 \%$;

- Uncertainty in $f_{\text {geol }}$ was assumed to be affected by the uncertainty of hydraulic conductivity. Uncertainty in $\mathrm{K}$ can be very high: even higher than the actual value of $\mathrm{K}$ (Gleeson et al., 2011; Tschritter et al., 2014). This study assumes that the maximum standard deviation in $\mathrm{K}$ is less than or equal to $\mathrm{K}$ itself. The uncertainty was further assumed to only play a role if the recharge was higher than $\mathrm{K}$ (with both recharge and $\mathrm{K}$ converted to match the monthly time step).

Rescaling the covariance matrix to the values of the uncertainty in the input components was done as follows:

$\sigma_{x y, \text { scaled }}^{2}=\sigma_{x y}^{2} \frac{\sigma_{x, \text { new }} \sigma_{y, n e w}}{\sigma_{x} \sigma_{y}}$,

where:

- $\sigma_{x y, \text { scaled }}^{2}$ is the scaled variance;

- $\sigma_{x y}^{2}$ is the variance from the covariance analysis;

- $\sigma_{x, \text { new }}$ and $\sigma_{y, \text { new }}$ are the errors in the input components;

- $\sigma_{x}$ and $\sigma_{y}$ are the standard deviations from the covariance analysis;

\section{Results}

\subsection{National rainfall recharge estimates}

Application of the NGRM leads to nation-wide estimates of rainfall recharge at monthly intervals at $1 \mathrm{~km}$ grid resolution (mean annual values shown in Figure 3). The time series of recharge and 
some model components for three randomly chosen locations are shown in Figure 4. Mean annual uncertainty is highest at places where rainfall is high (Figure 5, left). However, relative uncertainty, i.e., as a percentage of the mean annual recharge (Figure 5, right), is largest in areas where hydraulic conductivity is low. Recharge uncertainty is thus affected by rainfall for its high volumes, but most sensitive to geology for its high uncertainty and significant role in the model equation.

The total New Zealand average rainfall recharge for the period 2000 - 2014 estimated from the NGRM model is $2500 \mathrm{~m}^{3} / \mathrm{s}$, with a model uncertainty $\sigma$ of $17 \%$ (Table 4). Total rainfall recharge values for the North Island is $1334 \mathrm{~m}^{3} / \mathrm{s}$ (a mean of $370 \mathrm{~mm} / \mathrm{yr}, \sigma 15 \%$ ); for the South Island it is $1166 \mathrm{~m}^{3} / \mathrm{s}$ (a mean of $243 \mathrm{~mm} / \mathrm{yr}, \sigma 18 \%$ ). The national estimate falls within the $2835 \mathrm{~m}^{3} / \mathrm{s}(\sigma$ $10 \%$ ) recharge estimate of Döll and Fiedler (2008). Although their estimate is for a different period (1972-1990), rainfall in the different analysis periods appears relatively similar (1972 to 1990: 1881 $\mathrm{mm} / \mathrm{yr} ; 2000$ - 2013: $1839 \mathrm{~mm} / \mathrm{yr}$, according to VCS estimates).

\subsection{Comparison of rainfall recharge with published case studies}

NGRM recharge estimates were compared to lysimeters in the Canterbury Plains, New Zealand (Figure 6). These four dryland lysimeter stations, located in the plains ('Airport', 'Hororata', 'Lincoln', and 'Winchmore'), have measured rainfall recharge from 1999 (or earlier) onwards. Hong and White (2014) compared these lysimeter observations with two locally applied models (called SOILMOD/DRAIN and SMB-SMC) for the period 2000-2004. Mean annual NGRM rainfall recharge estimates for the same period are equal to rainfall recharge observations at three lysimeter stations (Table 5 and Figure 7): recharge values fall within the model uncertainty $\sigma$ at the Airport, Lincoln and Winchmore locations; at Hororata NGRM estimates much lower recharge, which is mainly caused by one anomalous rainfall event in January 2002 (Figure 8), where torrential rains occurred on the 1st of January, and heavy rain wreaked havoc and caused surface flooding along the east coast of Canterbury from 11-13 January (NIWA, 2002a, b). The locally calibrated SOILMOD/DRAIN model handles this anomalous wet event better at Hororata than the NGRM and SMB-SMC model.

NGRM rainfall recharge estimates were compared to a locally calibrated model in the Waimakariri Canterbury Water Management Strategy Zone, New Zealand (Figure 9). The regional council, Environment Canterbury (ECAN), developed an advanced land surface recharge model with a grid resolution of $200 \mathrm{~m}$ for this area Alkhaier (2016). This 'ECAN' model was built with the MIKESHE hydrological platform DHI (2016) and includes a sensitivity analysis with the PEST package (Doherty, 2016). The ECAN model gives mean recharge for the time period $1972-2015$ for three different model scenarios: a minimum, average, and maximum land surface recharge scenario (Figure 10). The 2000 - 2013 mean annual recharge (196 $\pm 27 \mathrm{~mm} / \mathrm{yr})$ agrees well with the ECAN model's minimum (195 mm/yr) scenario (Table 6). Comparing recharge for the two different time periods only creates a maximum estimation error of approximately $12 \mathrm{~mm} / \mathrm{yr}$, since mean (VCS) rainfall for the model area for 1972 - 2013 was $798 \mathrm{~mm} / \mathrm{yr}$; for 2000 - 2013 it was $763 \mathrm{~mm} / \mathrm{yr}$; 
and rainfall recharge was in between approximately 0.25 and 0.45 of rainfall for the different scesimilar for the NGRM and the ECAN models (110 mm/yr for NGRM compared to approximately $125 \mathrm{~mm} / \mathrm{yr}$ for the three ECAN scenarios). However, there are visual spatial differences between the NGRM and the ECAN recharge models, of which the clearest difference is in river areas, where ECAN recharge is high and NGRM recharge is low (see discussion section on river recharge). It seems more likely that the ECAN model is more realistic than the NGRM in these areas, since the ECAN model is calibrated. However, both models lead to the same mean annual recharge. To investigate which of the two models is best in which area requires more in-depth research that takes into account factors as: recharge in areas out of the model boundary (see discussion), groundwater table depths; spring locations, and baseflow separation methods at multiple gauging locations in the rivers.

Recharge data were compared in the mid-Mataura catchment, located in the Southland Region, New Zealand (Figure 11). The area for this case study consists of five groundwater management zones. The groundwater flow model developed for the mid-Mataura catchment (Burberry et al., 2013) used recharge values that were estimated for polygons with the Rushton method (Rushton et al., 2006). Mean annual recharge estimates between July 2000 and June 2007 of the NGRM and Rushton model in the five groundwater zones have been used for this comparison. Total mean annual NGRM recharge is lower than the Rushton estimate $(131 \pm 27 \mathrm{~mm} / \mathrm{yr}$ and $215 \mathrm{~mm} / \mathrm{yr}$, respectively, see Table 7). This is partly caused by the difference in rainfall used for both models $(809 \mathrm{~mm} / \mathrm{yr}$ for the NGRM model vs. $903 \mathrm{~mm} / \mathrm{yr}$ for the Rushton model). However, the ratio of recharge and rainfall of NGRM $(0.16 \pm 0.03)$ is still lower than the Rushton model (0.24). If Rushton and NGRM uncertainties would be similar, then recharge estimates NGRM would be $2 \sigma$ lower than the Rushton output. However, the Rushton polygons have an unknown but potentially large uncertainty, since there are so few polygons compared to the NGRM model cells (Figure 12). Rushton recharge estimates exclude areas outside the model boundaries that are still in the catchment. This could have implications for recharge occurring in areas in the catchment, but outside the model boundary (see discussion). Further local comparison should thus include an uncertainty estimate of the Rushton recharge, and should include the whole (sub-)catchment and not only the model boundary.

\section{Discussion}

NGRM rainfall recharge estimates, including their underlying input satellite data of AET, are a

valuable new addition to existing national datasets of terrestrial water cycle variables (Booker and Woods, 2014; Tait et al., 2006; Woods et al., 2006). For example, national water budgets based on long-term means can be aided by: estimates of baseflow using the long-term mean rainfall recharge; estimates of AET that include irrigation and interception; estimates of unrouted quickflow using the 
surface runoff that is stored by the model; and estimates of rainfall that are corrected for terrain slope, interception, and snow. Theoretically, a water budget can be made using all NGRM data. However, we acknowledge that implementation of a national water budget requires a much larger effort. This is because of many reasons, of which some are explained here. First, the NGRM model has model limitations, mostly due to its simplifications. Although NGRM matches case studies well in this paper, the model may be too simple in other (sub-)catchments. These model limitations are described below in the topic 'Model equation limitations'. Second, current national input datasets might not be good enough for application at the local scale. This is discussed in the topic 'Limitations and advantages of nation-wide model input data'. Third, considerable uncertainty remains in data-sparse regions such as irrigated and mountainous areas, which is discussed in the topics 'Uncertainty of NGRM in mountainous areas' and 'Uncertainty of the NGRM in irrigated areas'. Recommendations are compiled and discussed in a final topic 'Future Research'.

\subsection{Model equation limitations}

The NGRM is considered a simplified model that aims for: a national and inter-regional overview; relating differences in existing local models; and estimating rainfall recharge in unexplored territory. The modelled rainfall recharge and its uncertainty estimates are therefore also considered simplified, although recharge estimates and their uncertainty fit well to observed differences with measurements and other local models. Because the model has not been calibrated on a smaller scale, like local models, it has to use generic or simplified assumptions. These assumptions are discussed below.

The slope-runoff relation is based on a sparse dataset of empirical values by Döll and Fiedler (2008), who relate total recharge to a slope correction factor. Other relations were explored, but none better were found for use on the national scale. Probably the best-known alternative is a curve number (CN) approach relating soil type and land cover to runoff (Cronshey, 1986). This method has been developed for gently sloping hills in the United States and might not be able to deal with steeper slopes, e.g., New Zealand mountainous terrain. Other rainfall recharge models use a relation between rainfall intensity and soil (Rushton et al., 2006; Westenbroek et al., 2010) without taking into account terrain slope. The NGRM prefers to use the simple relation to terrain slope, because of three reasons. First of all, rainfall intensity is not captured well on a monthly scale. Second, we are of the opinion that steeper slopes lead to rainfall 'splash' (Hendriks, 2010) and can form preferential flow channels, ultimately adding to surface runoff. Third, terrain slope is inherently related to soil. For example, regardless of mean annual precipitation, long-term mean denudation rate in river basins is proportional to basin relief Ahnert (1970); Summerfield and Hulton (1994), leaving less erodible material (e.g., soil) on the steep slopes, which amplifies the splash effect.

A simple snow correction was assumed to estimate rainfall from precipitation. This correction factor was based on a coarse assumption that precipitation is snow when temperature is below $0^{\circ} \mathrm{C}$. A better defined snow-rainfall relation should be implemented in future updates of the NGRM. 
Another shortcoming of this simple correction is snowmelt: in Spring a substantial amount of the snow will melt, which is likely to substantially recharge the groundwater and have a large impact on the whole water budget White (2007). Further research should therefore be applied to implement a module of 'snow correction and snowmelt recharge'.

Heterogeneity and model up-scaling and down-scaling could cause a large, but unknown uncertainty, e.g., averaging high resolution soil and subsurface parameterisation over a $1 \mathrm{~km}$ grid cell. Furthermore, averaging slope for $1 \mathrm{~km}$ grid cells could lead to a wrong estimate of runoff, which would loop back to wrong recharge and more uncertainty in the slope-runoff relation. A higher resolution representation of elevation and slope was not implemented at the national scale, since that would require significantly more computational power. For example, a typical run for 2000 to 2013 now takes 1 hour on a standard desktop computer. Using higher resolution data, such as $100 \mathrm{~m}$, would make the input datasets 100 times larger, and parallelisation would need to be implemented for more efficient computation. However, smart solutions can be explored, e.g., by compiling the high resolution only as spatial statistics of a $1 \mathrm{~km} \mathrm{x} 1 \mathrm{~km}$ pixel, instead of using the full high resolution data arrays. Future research on application of the NGRM model on the local scale should therefore address these issues of scaling and heterogeneity.

Hydraulic conductivities of the underlying geology in this research are given for saturated flow. $\mathrm{K}$ values for unsaturated flow can be lower than for saturated flow, but they are non-linear and not easy to estimate Hendriks (2010); Fitts (2013). The simple NGRM model does not calculate unsaturated $\mathrm{K}$ vales for several reasons. First, since the uncertainty in $\mathrm{K}$ is already high and was therefore in the model equation already clipped to the actual value of $\mathrm{K}$. Second, it was considered to adjust $\mathrm{K}$ relative to soil water deficit by simply choosing a lower value of saturated K, e.g., $75 \%$ of saturated $\mathrm{K}$. This option is very arbitrary, and in most cases it does not inhibit any recharge in porous and wet media (i.e. aquifers), as the recharge values are much smaller than the hydraulic conductivity. Third, we assume that preferential flow paths through soil can play a much larger role than the decreased hydraulic conductivity in most unconsolidated aquifers, as well as in most rock types (through faults and cracks). Therefore, and for the sake of simplicity of the NGRM model, it was chosen not to incorporate any calculations of unsaturated flow.

The rainfall recharge estimated by the NGRM model is a 'potential recharge', i.e., the recharge that would occur if the groundwater table is deep enough. Shallow groundwater tables will result in partial rejection of rainfall recharge, and a larger component might go to runoff or evaporation in these areas, which at this stage cannot be modelled by the NGRM model. Therefore, it is recommended to couple the NGRM with groundwater models, so that recharge can be corrected in areas such as wetlands or springs. This coupling process can then indicate areas where potential recharge can be corrected to actual recharge.

465 Finally, the NGRM (as well as the WaterGAP) model does not calculate the recharge of rivers to groundwater (except for rainfall on dry riverbeds). In some areas with large braided gravel river 
systems, losing rivers can recharge groundwater substantially, especially when streamflow is high and groundwater level is low (e.g., after heavy rainfall following a long dry period in autumn). Recent research on nation-wide work on losing and gaining rivers is reported by Yang et al. (2015).

Therefore, future development of the NGRM is recommended to use results of that work.

\subsection{Limitation of model input data}

We considered that model input data of the NGRM model is much finer, and probably better, than that of the large-scale WaterGAP model. However, application of the NGRM model on the local scale, as should every model, should embed a careful consideration of the quality of model input data.

For rainfall, the largest model input data component, NGRM application at the local scale reveals bias rather than uncertainty. For example, the national (VCS) rainfall data in the Waipa River catchment of the Waikato region, New Zealand, had to be increased by $15 \%$ by Rawlinson et al. (2015) in order to make it fit with the values of three independent models. Systematic errors or biases in model input components propagate differently from uncertainty as calculated by the NGRM model equations. For example, a consistent bias in monthly rainfall, where there is under-catch, i.e., real rainfall is higher than measured rainfall, would lead to a different uncertainty of rainfall recharge model estimates.

Although ET is generally smaller than rainfall, the estimation of PET and AET also has considerable uncertainty. Westerhoff (2015) demonstrated that uncertainty in daily Penman PET in New Zealand can be $10-40 \%$. For this study, it was assumed that the uncertainty of AET decreases with the AET/PET ratio. Because AET depends on more parameters than PET, e.g., soil moisture and vegetation health, the effect of the uncertainty of those parameters is unknown. This is one of the reasons that AET is often estimated from PET at the local scale, because soil parameters are considered to be better known at that scale. Furthermore, satellite-derived AET is known to contain errors in areas with steep topography. Although MOD16 AET (2000-2013) compares better to lysimeterderived AET (1999-2011) in the Canterbury Plains than the average 1960-2006 AET as described by Woods et al. (2006) (Figure 13), it does not necessarily mean it is better in every region.

More detailed research of canopy interception of the rainfall, and LAI, will improve model estimates. However, since the uncertainty of interception was assumed small in comparison with rainfall and ET this will not be discussed here.

Comparison of the NGRM with the ECAN model in the Waimakariri catchment (see Results) showed that land surface recharge of the ECAN model is much higher in the river. This is not caused by a shortcoming of the model equation (as the ECAN model also does not embed a river recharge model), but by the differences in available soil data. The ECAN recharge model uses a local, more spatially detailed, soil data set, which is not available at the national scale. These local data account better for recharge in the very permeable river areas. 


\subsection{Uncertainty of the NGRM in mountainous areas}

The NGRM model indicates that rainfall recharge can be larger in mountainous areas, e.g., the flanks aquifers is unlikely in mountainous areas, rainfall recharge is likely to occur in these areas. This recharge is mostly caused by a high rainfall climate: although the geology seems relatively impermeable and much runoff is expected, substantial amounts of rainfall can still permeate into the ground. For example, Sims et al. (2015) surmise that a maximum of $20 \%$ of rainfall could infiltrate schist bedrock in the Southern Alps, New Zealand. These amounts could recharge to small, perched, aquifers to enter as baseflow at relatively short distance. This is likely to occur in the higher regions of Canterbury or most of the West Coast on the South Island. Alternatively, groundwater could recharge to (unknown zones of) deep groundwater. For example, Calmels et al. (2011) find deep groundwater, likely to come from the mountainous region in Taiwan, with a similar high-rainfall climate and terrain to New Zealand. Doyle et al. (2015) show that $45 \%$ of aquifer recharge originates from mountain blocks in their study area in British Columbia, Canada.

The uncertainty of rainfall recharge is, however, largest within mountainous regions. This is because, for low hydraulic conductivity, the large uncertainty of $\mathrm{K}$ plays a significant role in the recharge model uncertainty (e.g., Figure 5, right). Additionally, low permeability and high rainfall can cause overestimation of recharge in monthly estimates: the model assumes that this falls evenly over the month, but the monthly rainfall is realistically the result of a few high-rainfall events that lasted not more than days or shorter. Daily estimates would improve recharge estimation in mountainous regions, but this would also impact the speed and simplicity of the model. Finally, recharge can be underestimated due to under-representation of fractures and faults in the model. Fractured zones, common in mountainous areas, are currently only partly embedded in the estimation of $\mathrm{K}$ (as the method of Gleeson et al. (2011) is partly based on calibration of multiple hydrological models in hard-rock formations.

Comparisons with locally calibrated models in this research (Waimakariri and Mataura) show that the NGRM model estimates a low mean recharge (when uncertainty is not taken into account). As known, calibrated models do not take into account recharge that occurs outside the model boundaries. Recharge in the foothills or in mountainous area is thus not taken into account in these models, since they are not within the model boundary. If recharge outside the model boundaries would occur in reality, but models do not take this into account, then those models would be calibrated wrongly. Future local recharge models should therefore consider taking into account at least the scale of the whole catchment, i.e. including the foothills and mountains. It is recommended to perform more research on mountain recharge, its relation to deep groundwater, and its relation to fracture zones, and implications for model calibration and model time steps. 


\subsection{Uncertainty of the NGRM in irrigated areas}

In irrigated areas, the soil storage receives an additional irrigated amount of water. This is only partly incorporated in the NGRM. The effect of irrigation and interception is taken into account by the AET, since the independent satellite-derived signal picks up vegetation health. Use of an independent satellite-derived signal is thus advantageous: it means that the AET is calculated as higher in these areas as the vegetation health has increased. Other parts of the model cannot always cope well with irrigation. For example, if irrigation is not fully efficient, (i.e., the water drains to groundwater instead of feeding the crop), the excess water will recharge and create an unknown bias in the monthly soil storage of the NGRM model. If water abstraction for irrigation comes from groundwater, the long-term effect of this excess irrigation recharge (a positive flux to recharge) will balance the water abstraction (a negative flux to recharge). However, if irrigation comes from surface water, this could impact both the monthly and the long term estimates of the NGRM recharge estimation. If national irrigation data become readily available, it is recommended to add these to the model equation. However, estimating exact volumes of irrigation is not straightforward and could result in other, much larger, bias of the model estimates. Use of the satellite-derived AET could help in better estimates of irrigated and non-irrigated areas. Furthermore, use of the MOD16 PET in a ratio of AET to PET could give a better, measured, indication of soil water deficit, which could be fed back into the NGRM model.

\subsection{Future research}

This discussion highlights the need for further research on application of adjusted large-scale models and satellite data on the national or regional scale. Future research for improvements in the NGRM model is summarised as:

- Model improvements on rainfall-runoff, river recharge, snow and snowmelt, soil heterogeneity, hydraulic conductivity;

- Better uncertainty assessment of national input data, such as rainfall and AET;

- Incorporation of larger (catchment-based) model boundaries in future local and regional recharge studies;

- Correction of recharge through coupling with groundwater models in wetlands and springs;

- The effect of mountain recharge to groundwater modelling in New Zealand;

- The added value of satellite-derived AET in irrigated areas.

The NGRM model is inspired by international, global-scale, researchers. If the NGRM model would be applied by regional councils, there is a need for further improvement of model equations and uncertainty estimates of both the model as well as its input components, e.g., rainfall and 
AET. Future research should therefore be performed in a catchment-by-catchment analysis with the best available data from regional councils, i.e., regional streamflow data and water budgets per subcatchment. In data-sparse regions, the regional data could then be completed with national flow data and statistics (e.g., Woods et al., 2006; Booker and Woods, 2014) from national research organisations. This recommended research can be best applied in a collaborative environment, with regional councils, national research organisations, and international researchers. In this context, all the mentioned topics of research lead to one overall recommendation, i.e., more and better collaboration between international research of large-scale models and data with national and regional stakeholders in the research fields of groundwater and surface water. International and national research funds should further stimulate this collaborative approach.

\section{Conclusions}

This paper developed an approach to use large-scale, global, models and satellite data to estimate rainfall recharge at the national scale, i.e., across New Zealand, and smaller. The model, NGRM, uses an adjustment of the WaterGAP model, and MODIS derived ET and vegetation data, and furthermore the available nation-wide datasets on rainfall, elevation, soil and geology. The NGRM estimates $1 \mathrm{~km}$ x $1 \mathrm{~km}$ monthly nation-wide rainfall recharge from January 2000 to December 2013. A valuable addition to the recharge estimation is the model uncertainty estimate (not typically output from previous rainfall recharge models in New Zealand), based on variance and covariance analyses, and model sensitivity of input components in the model environment. As opposed to the WaterGAP model, the NGRM model utilises better national input data of rainfall, soil, elevation, geology. The estimated total New Zealand average recharge of the NGRM model results compiles to approximately $2,500 \mathrm{~m}^{3} / \mathrm{s}$, or $298 \mathrm{~mm} / \mathrm{yr}$, with a model uncertainty of $17 \%$, and is similar to the WaterGAP model.

Although the NGRM model is uncalibrated, its recharge estimates compare well to most local and regional lysimeter data and recharge models. From the case study comparisons it is concluded that the nation-wide rainfall recharge model gives a valuable initial estimate when applied at the local or regional scale, and can thus also be used in areas as a valuable initial estimate in data-sparse areas. Local applications might require the model to be calibrated and, as with any model, it is therefore recommended to carefully consider the NGRM model limitations for local application, but moreover the limitations of its nation-wide input data (such as rainfall and geology), as these seem to cause the largest uncertainty. This research also provides improved insights into the uncertainty of rainfall recharge models, including the role of recharge model input components. It shows that recharge is most sensitive to rainfall in areas where recharge is high, but that uncertainty in hydraulic conductivity plays an important role in areas where recharge is impeded by geology. Future research topics for application of large-scale models at the smaller scale are recommended to focus on collabora- 
Hydrol. Earth Syst. Sci. Discuss., doi:10.5194/hess-2016-410, 2016

Manuscript under review for journal Hydrol. Earth Syst. Sci.

Published: 30 August 2016

(c) Author(s) 2016. CC-BY 3.0 License.

tive research between international and national researchers and the water managers (in this case the regional councils). Topics for future (collaborative) research are, amongst others, improvement of rainfall-runoff, snowmelt and river recharge, improvement of estimates of rainfall and evapotranspiration, and the added value of satellite-derived AET in irrigated areas. Finally, the impact of heterogeneity and spatial scaling in elevation, soil and geology input data sets, as well as the impact of fracture zones on rainfall recharge within mountainous areas require more research.

\section{Acknowledgements}

This research is part of a PhD study of the main author at the University of Waikato, New Zealand, supervised by Prof. Moira Steyn-Ross. It has been performed as part of the Smart Aquifer Character-

615 isation (SAC) Programme, funded by the Ministry of Business, Innovation and Employment, New Zealand. This project has received co-funding from the European Union's Seventh Programme for research technological development and demonstration under grant agreement No 603608, eartH2Observe. We furthermore would like to thank: Andrew Tait from NIWA for generously sharing gridded VCS data; Taejin Park, PhD student at Boston University, Department of Earth and Environment, Cliveg

620 Research Group, for sharing the LAI dataset; Fouad Alkhaier from Environment Canterbury for sharing data on the Waimakariri recharge; and Catherine Moore (GNS Science) for providing data of the mid-Mataura catchment. 
Hydrol. Earth Syst. Sci. Discuss., doi:10.5194/hess-2016-410, 2016

Manuscript under review for journal Hydrol. Earth Syst. Sci.

Published: 30 August 2016

(c) Author(s) 2016. CC-BY 3.0 License.

Table 1. New Zealand hydrolithologies and their intrinsic permeability $\kappa$, including standard deviation $\sigma_{\kappa}$, after Gleeson et al. (2011) and improved for the New Zealand context. F-g. = fine-grained; p-s. = poorly sorted; c-g. = coarse-grained; uncons. $=$ unconsolidated; sed. $=$ sedimentary.

\begin{tabular}{llll}
\hline Hydrolithology unit & $\kappa$ & $\begin{array}{l}\sigma_{\kappa} \\
{\left[\log \mathrm{m}^{2}\right]}\end{array}$ & Example \\
& -16.5 & 1.7 & mudstone, claystone \\
\hline F-g. sed. & -15 & 1.5 & granite, greywacke \\
Crystalline & -14 & 1.8 & clay, silt \\
F-g. uncons. sed. & -14 & 1.8 & limestone, shell beds \\
Carbonate & -12.5 & 1.8 & andesite, basalt \\
Volcanic & -12.5 & 1.8 & turbidite, breccia \\
P-s. sed. & -12.5 & 1.8 & peat, till \\
P-s. uncons. sed. & -12.5 & 0.9 & sandstone, greenstone \\
C-g. sed. & -11.6 & 1.8 & ignimbrite; scoria \\
Volcanic, high permeability & -10.5 & 1.2 & gravel; sand \\
C-g. uncons. sed. & & & \\
\hline
\end{tabular}

Table 2. Soil permeability ratios, empirically chosen from soil qualitative permeability classes from Newsome et al. (2008).

\begin{tabular}{lcc}
\hline Class name & Qualitative class & Permeability ratio \\
\hline $\mathrm{S}$ & Slow & 0.05 \\
$\mathrm{~S} / \mathrm{M}$ & Slow over moderate & 0.15 \\
$\mathrm{~S} / \mathrm{R}$ & Slow over rapid & 0.25 \\
$\mathrm{M} / \mathrm{S}$ & Moderate over slow & 0.15 \\
$\mathrm{M}$ & $\quad$ Moderate & 0.5 \\
$\mathrm{M} / \mathrm{R}$ & Moderate over rapid & 0.6 \\
$\mathrm{R}$ & $\quad$ Rapid & 0.95 \\
$\mathrm{R} / \mathrm{M}$ & Rapid over moderate & 0.8 \\
$\mathrm{R} / \mathrm{S}$ & Rapid over slow & 0.25 \\
\hline
\end{tabular}


Hydrol. Earth Syst. Sci. Discuss., doi:10.5194/hess-2016-410, 2016

Manuscript under review for journal Hydrol. Earth Syst. Sci.

Published: 30 August 2016

(c) Author(s) 2016. CC-BY 3.0 License.
Hydrology and

Discussions

Table 3. PAW classes and their descriptions, after Newsome et al. (2008).

\begin{tabular}{lccc}
\hline PAW Class & min. PAW $(\mathrm{mm})$ & $\max$. PAW $(\mathrm{mm})$ & Description \\
\hline 1 & 250 & 350 & Very high \\
2 & 150 & 249 & High \\
3 & 90 & 149 & Moderately high \\
4 & 60 & 89 & Moderate \\
5 & 30 & 59 & Low \\
6 & 0 & 29 & Very low \\
\hline
\end{tabular}

Table 4. 2000-2014 mean rainfall recharge values of the NGRM compiled for New Zealand, the North Island and the South Island, including model uncertainty.

\begin{tabular}{ccc}
\hline & $\mathbf{m}^{3} / \mathbf{s}$ & $\mathbf{m m} / \mathbf{y r}$ \\
\hline New Zealand & $2500 \pm 414$ & $298 \pm 49$ \\
North Island & $1,334 \pm 199$ & $370 \pm 55$ \\
South Island & $1,165 \pm 212$ & $243 \pm 44$ \\
\hline
\end{tabular}

Table 5. Mean annual rainfall recharge for July 2000 - June 2004 for four Canterbury lysimeters stations and the NGRM model. All values are in $\mathrm{mm} / \mathrm{yr}$.

\begin{tabular}{rcc}
\hline Location & Lysimeter & NGRM \\
\hline Airport & 156 & $163 \pm 23$ \\
Hororata & 230 & $139 \pm 27$ \\
Lincoln & 68 & $67 \pm 33$ \\
Winchmore & 212 & $195 \pm 25$ \\
\hline
\end{tabular}

Table 6. Mean annual recharge for the Waimakariri catchment management zone model area ( $\mathrm{mm} / \mathrm{yr})$

\begin{tabular}{rcccc}
\hline & NGRM & ECAN Min & ECAN Average & ECAN Max \\
\hline Minimum & 2 & 0 & 0 & 0 \\
Maximum & 432 & 661 & 661 & 664 \\
Mean & $196 \pm 27$ & 195 & 247 & 362 \\
StDev of spatial distribution & 110 & 126 & 127 & 120 \\
\hline
\end{tabular}


Hydrol. Earth Syst. Sci. Discuss., doi:10.5194/hess-2016-410, 2016

Manuscript under review for journal Hydrol. Earth Syst. Sci.

Published: 30 August 2016

(c) Author(s) 2016. CC-BY 3.0 License.

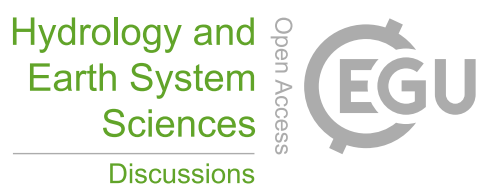

(c) (1)

Table 7. Mean annual rainfall and recharge for the Mid-Mataura model area ( $\mathrm{mm} / \mathrm{yr})$ for the NGRM and the

Rushton model

\begin{tabular}{rcc}
\hline & NGRM & Rushton \\
\hline Rainfall & 809 & 903 \\
Recharge & $131 \pm 27$ & 215 \\
RR ratio & $0.16 \pm 0.03$ & 0.24 \\
\hline
\end{tabular}


Hydrol. Earth Syst. Sci. Discuss., doi:10.5194/hess-2016-410, 2016

Manuscript under review for journal Hydrol. Earth Syst. Sci.

Published: 30 August 2016

(c) Author(s) 2016. CC-BY 3.0 License.
Hydrology and Earth System Sciences

Discussions

(c) (1)

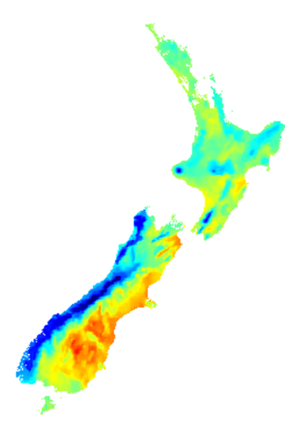

(a)
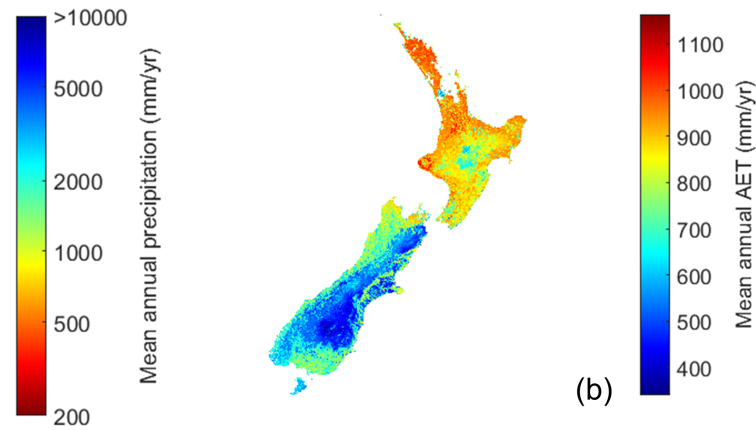

(b)

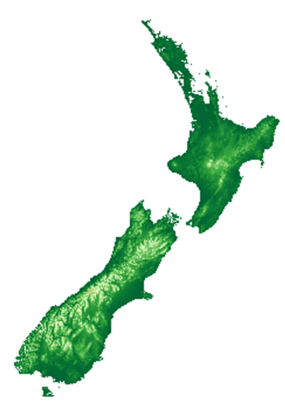

(c)
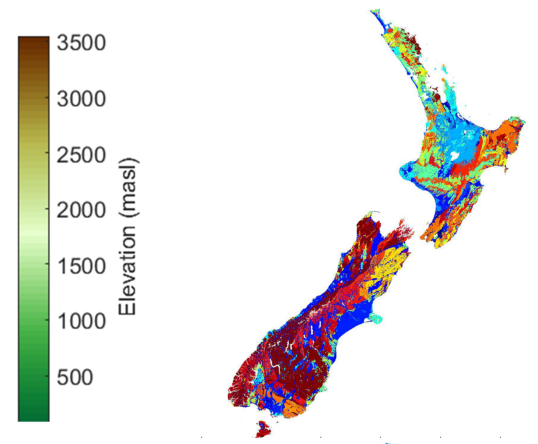

(d)
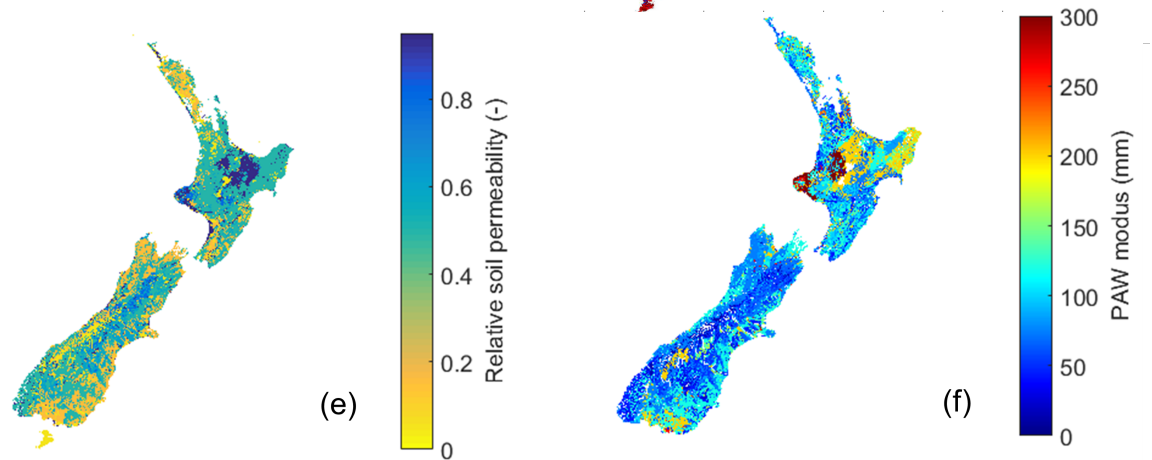

Figure 1. Overview of NGRM model input components of (a) precipitation (compiled to mean annual); (b) AET (compiled to mean annual values); (c) elevation; (d) hydraulic conductivity K; (e) soil permeability (here shown as a ratio, according to Table 2); and (f) PAW. 
Hydrol. Earth Syst. Sci. Discuss., doi:10.5194/hess-2016-410, 2016

Manuscript under review for journal Hydrol. Earth Syst. Sci.

Published: 30 August 2016

(c) Author(s) 2016. CC-BY 3.0 License.

\section{(c) (1)}

\section{Hydrology and Earth System \\ Sciences \\ Discussions}
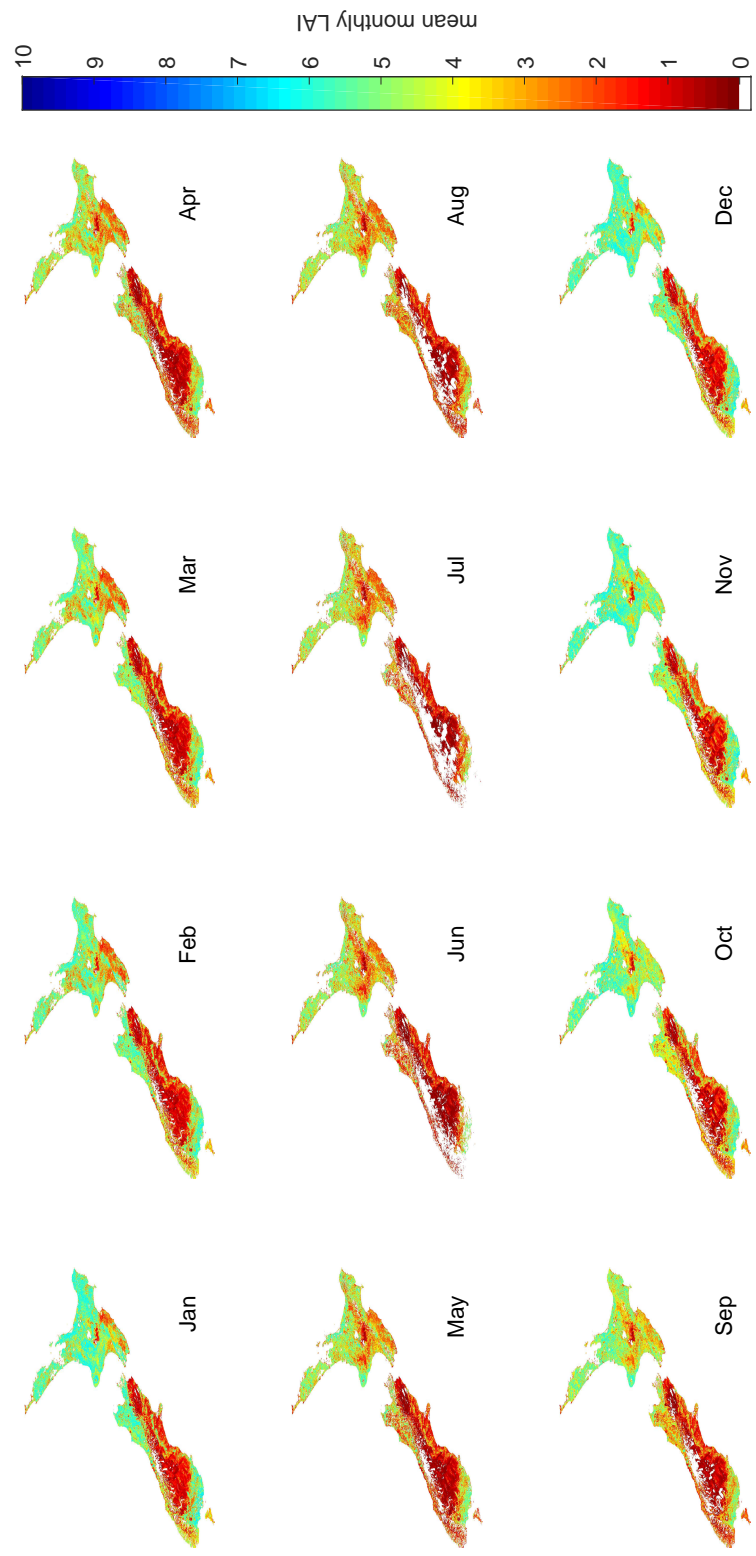

Figure 2. LAI climatology (2000-2013), compiled from Park (2015) and Samanta et al. (2011). 
Hydrol. Earth Syst. Sci. Discuss., doi:10.5194/hess-2016-410, 2016

Manuscript under review for journal Hydrol. Earth Syst. Sci.

Published: 30 August 2016

(c) Author(s) 2016. CC-BY 3.0 License.

\section{(c) (1)}

\section{Hydrology and Earth System Sciences \\ Discussions}

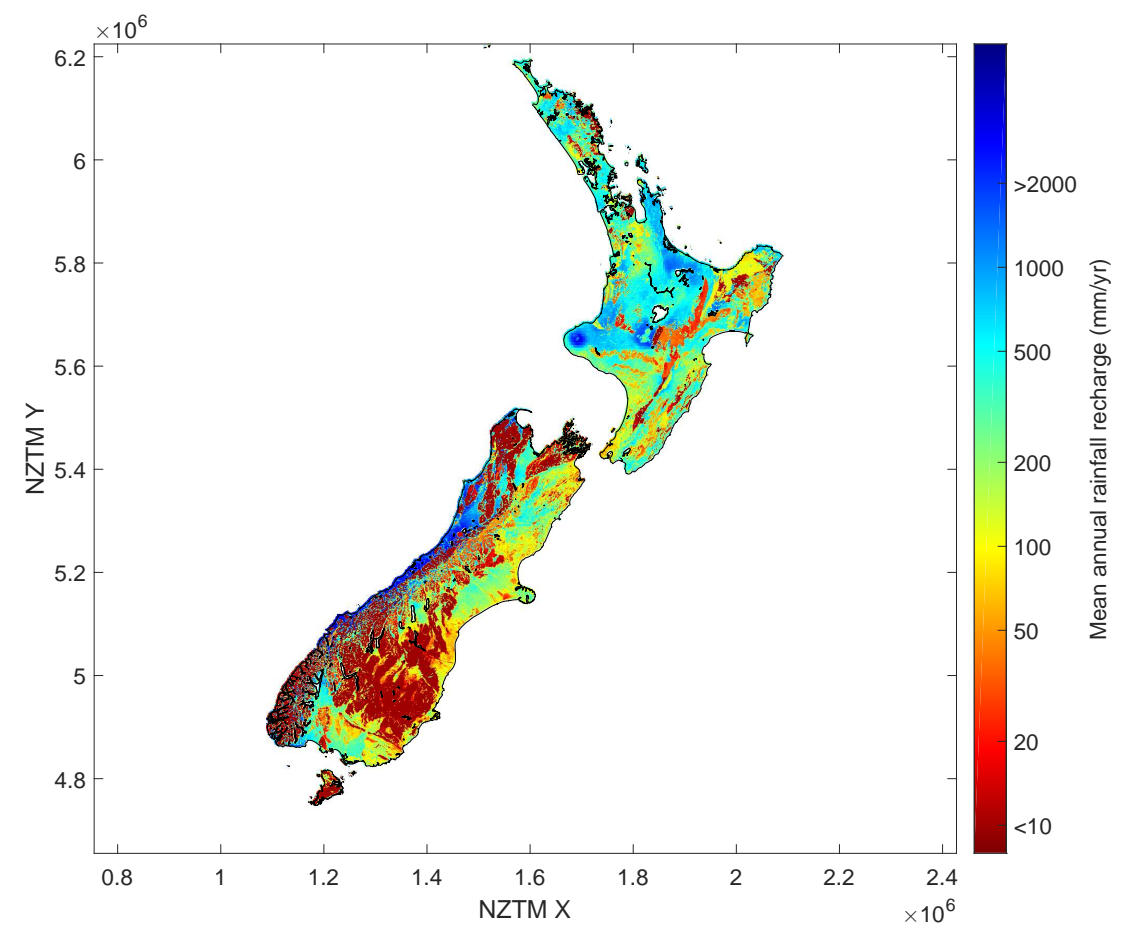

Figure 3. Nation-wide rainfall recharge from the NGRM compiled to mm/year. 
Hydrol. Earth Syst. Sci. Discuss., doi:10.5194/hess-2016-410, 2016
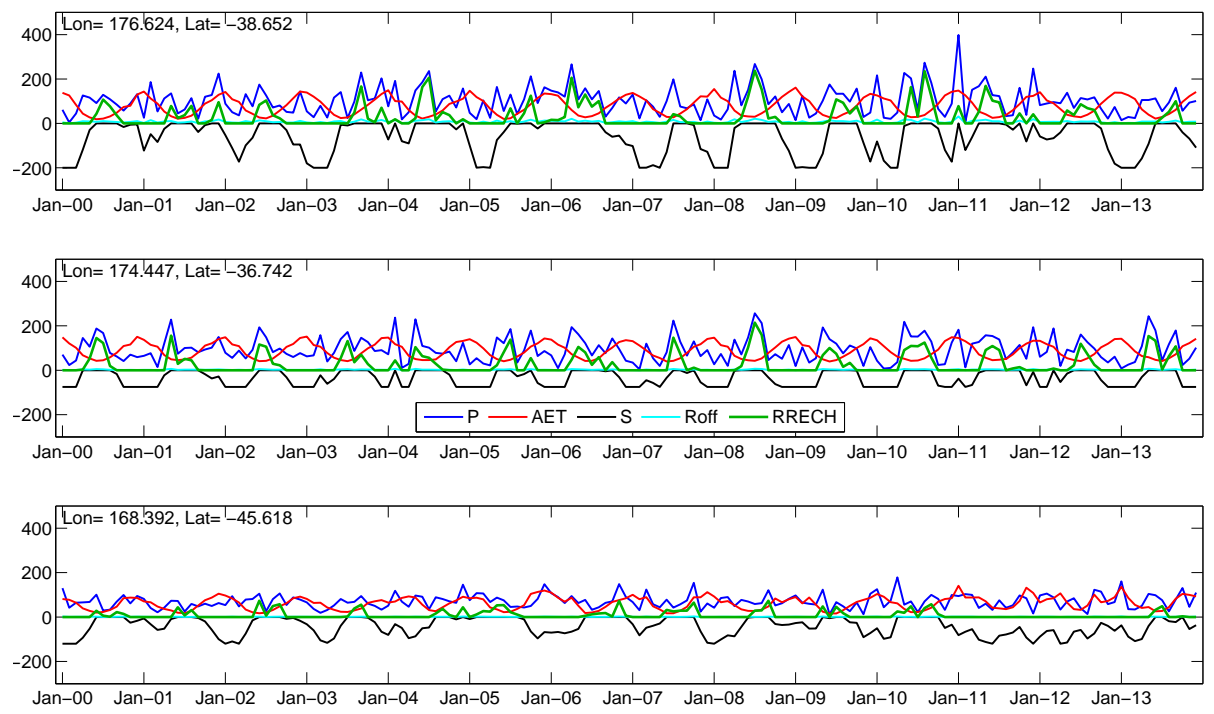

Figure 4. NGRM model components for three randomly chosen locations over the entire simulation period: rainfall (P), actual evapotranspiration (AET), soil storage (S), surface quickflow (Roff), and rainfall recharge (RRECH).
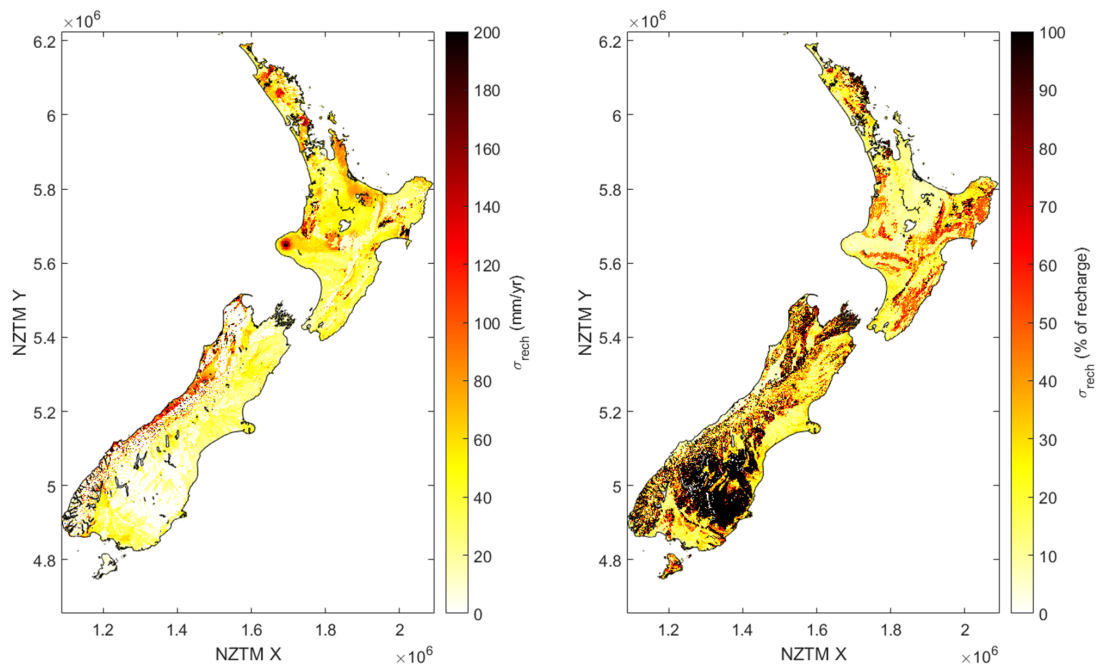

Figure 5. Uncertainty $\sigma_{r e c h}$ of mean annual rainfall recharge estimated with the NGRM model as $\mathrm{mm} / \mathrm{yr}$ (left) and as a percentage of total recharge (right). 
Hydrol. Earth Syst. Sci. Discuss., doi:10.5194/hess-2016-410, 2016

Manuscript under review for journal Hydrol. Earth Syst. Sci.

Published: 30 August 2016

(c) Author(s) 2016. CC-BY 3.0 License.
Hydrology and Earth System Sciences

Discussions (c) (i)

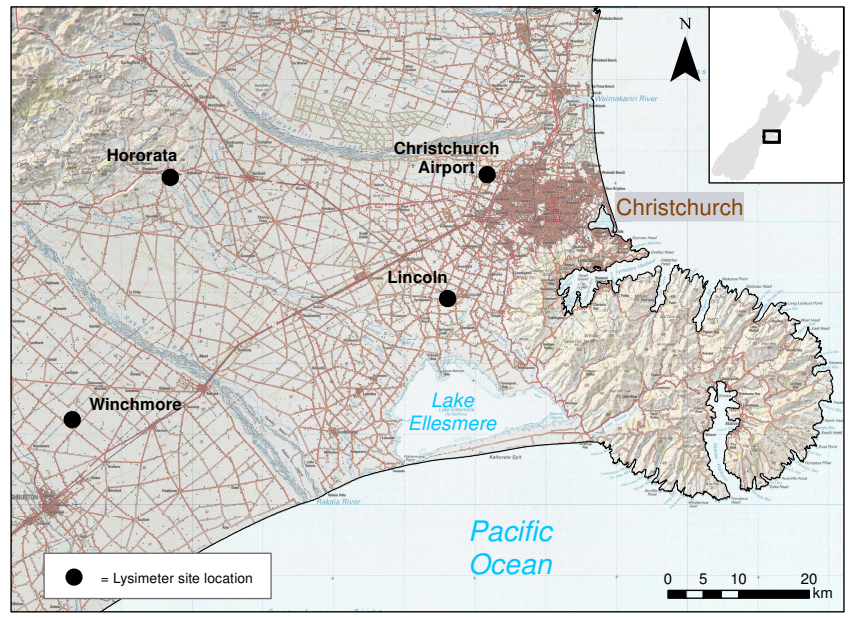

Figure 6. Lysimeter sites in the Canterbury Region. Adapted from: White et al. (2014)

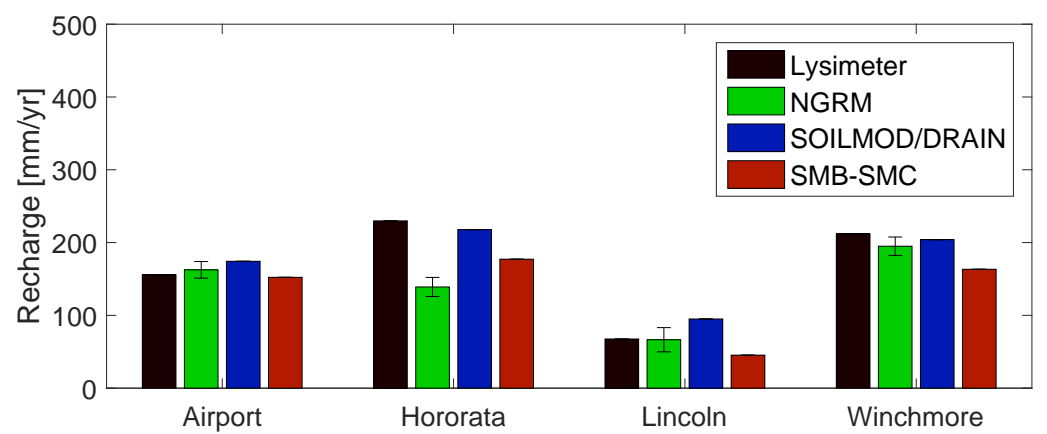

Figure 7. Comparison of recharge from lysimeter measurements to the NGRM model and other models (SOILMOD/DRAIN and SMB-SMC) for the period July 2000 - June 2004. The error bars indicate the NGRM model uncertainty. 
Hydrol. Earth Syst. Sci. Discuss., doi:10.5194/hess-2016-410, 2016

Manuscript under review for journal Hydrol. Earth Syst. Sci.

Published: 30 August 2016

(c) Author(s) 2016. CC-BY 3.0 License.

\section{(c) (1)}

Hydrology and Earth System Sciences

Discussions

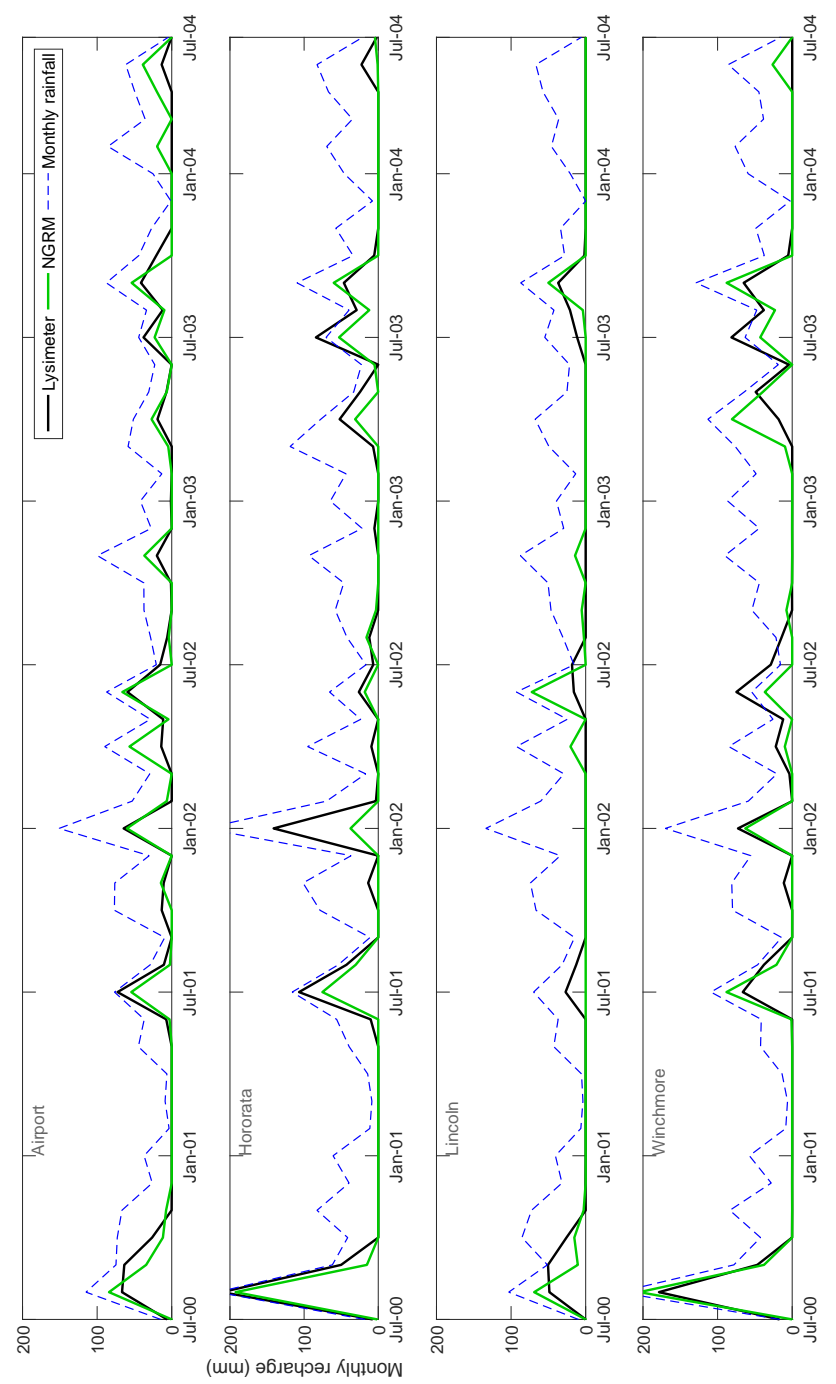

Figure 8. Montly estimated NGRM rainfall recharge (green) with observed lysimeter data (black) for the period July 2000 - June 2004. 
Hydrol. Earth Syst. Sci. Discuss., doi:10.5194/hess-2016-410, 2016

Manuscript under review for journal Hydrol. Earth Syst. Sci.

Published: 30 August 2016

(c) Author(s) 2016. CC-BY 3.0 License.

Hydrology and

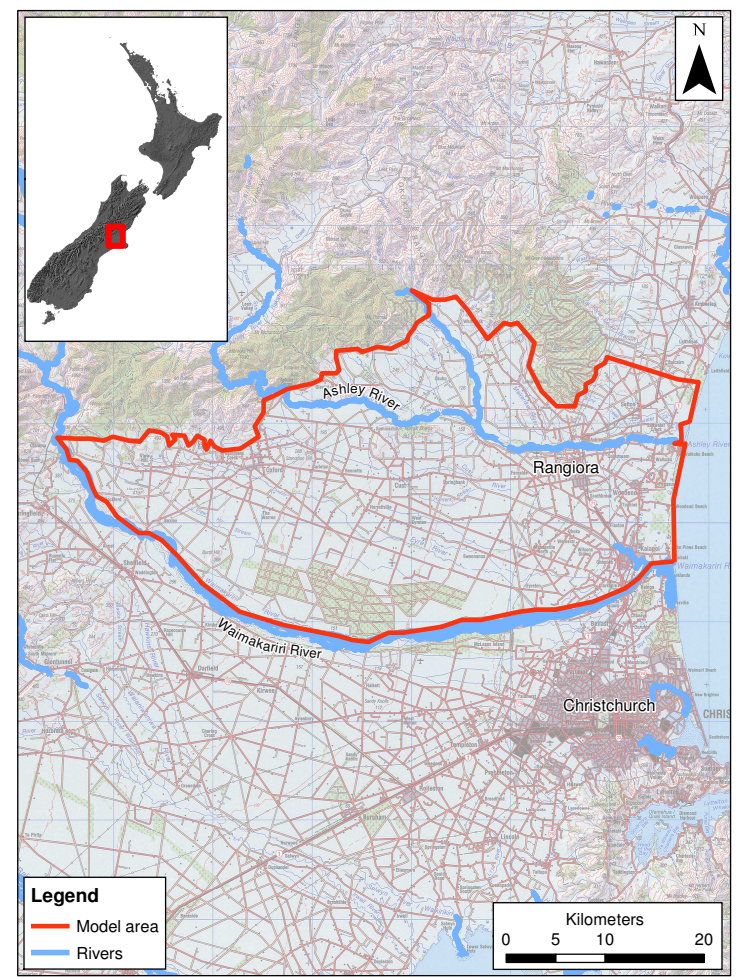

Figure 9. Model area in the Waimakariri catchment management strategy zone, Canterbury, New Zealand. 
Hydrol. Earth Syst. Sci. Discuss., doi:10.5194/hess-2016-410, 2016

Manuscript under review for journal Hydrol. Earth Syst. Sci.

Published: 30 August 2016

Hydrology and Earth System Sciences (c) Author(s) 2016. CC-BY 3.0 License.
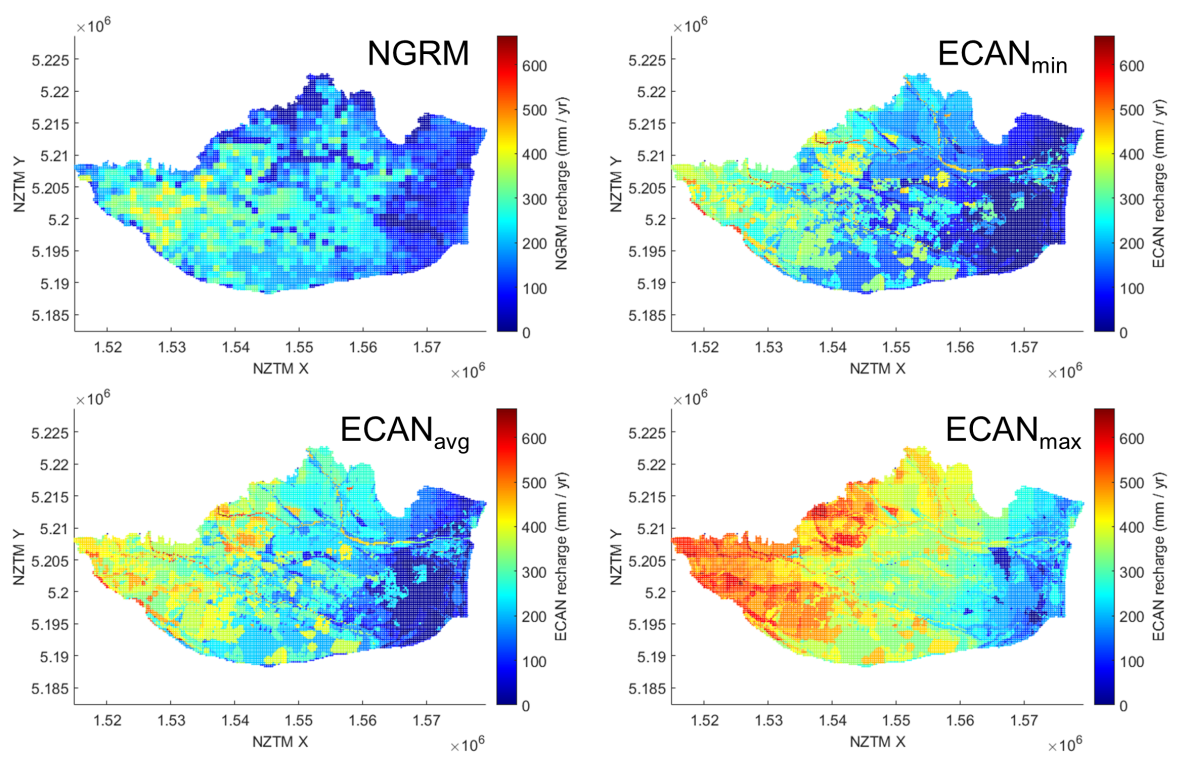

Figure 10. Mean annual recharge in Waimakariri catchment management strategy zone. Left: NGRM recharge. Right: Recharge as evaluated by the ECAN land surface recharge model.

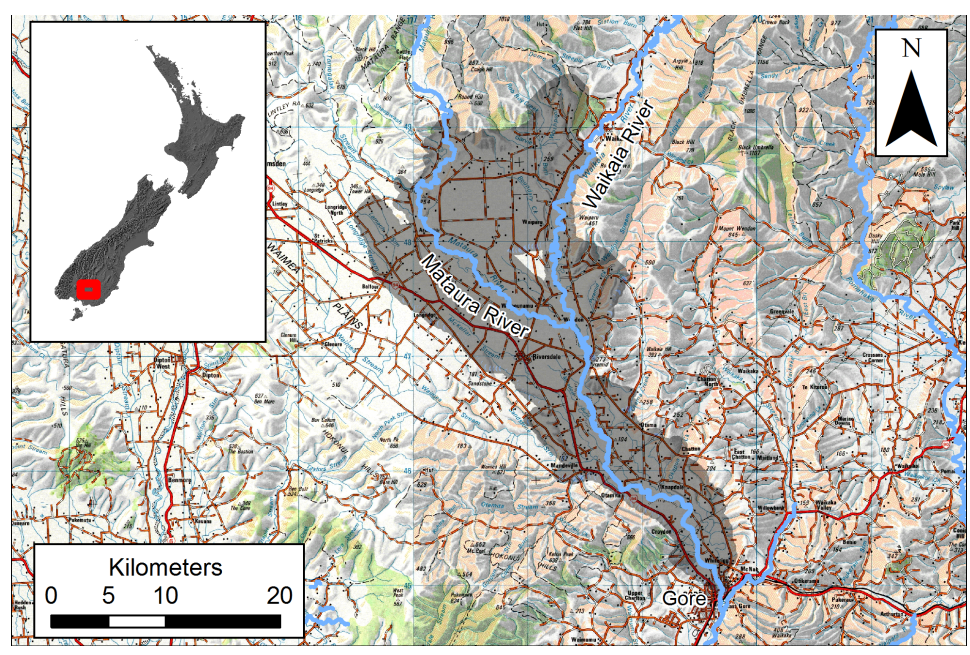

Figure 11. Groundwater zones in the mid-Mataura catchment, Southland, New Zealand. 
Hydrol. Earth Syst. Sci. Discuss., doi:10.5194/hess-2016-410, 2016

Manuscript under review for journal Hydrol. Earth Syst. Sci.

Published: 30 August 2016
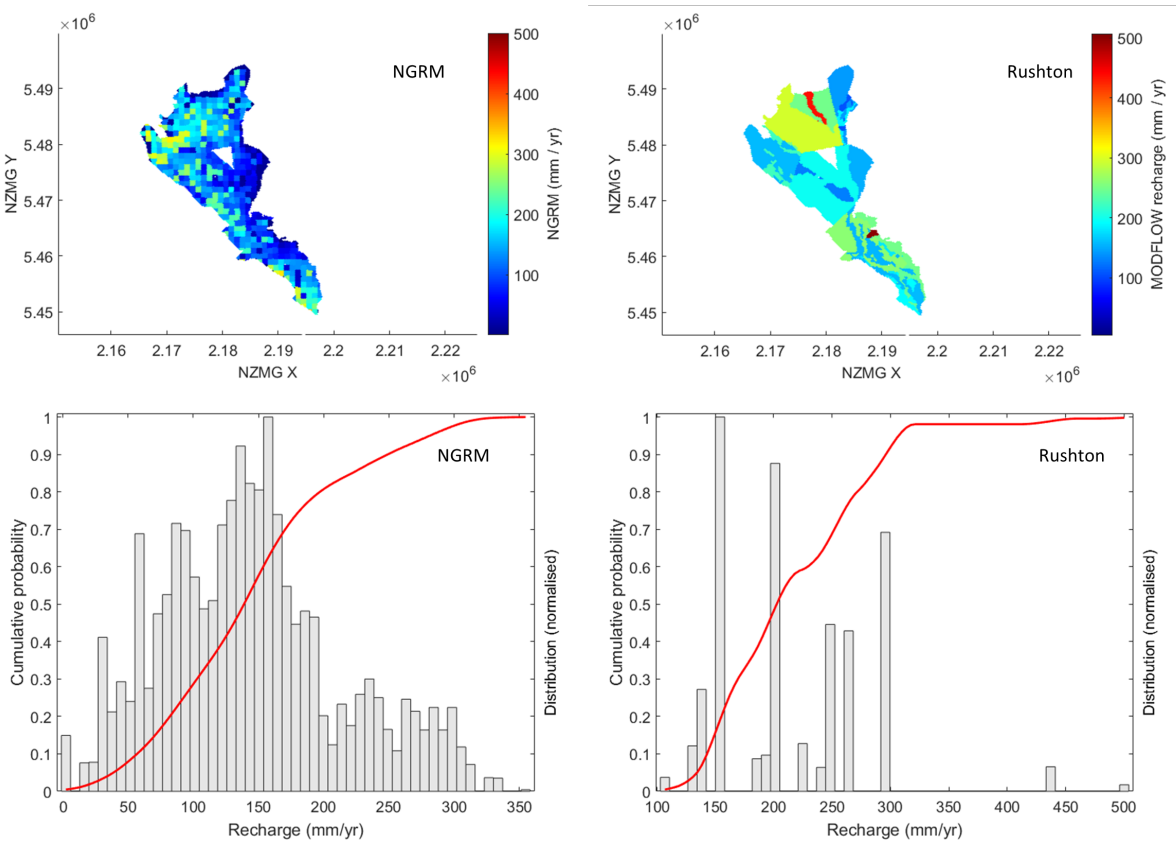

Figure 12. Mean annual recharge and its spatial distribution in the mid-Mataura catchment model area, according to the NGRM (left) and the Rushton (right) models. Cumulative probability in the bottom figures is shown in red.

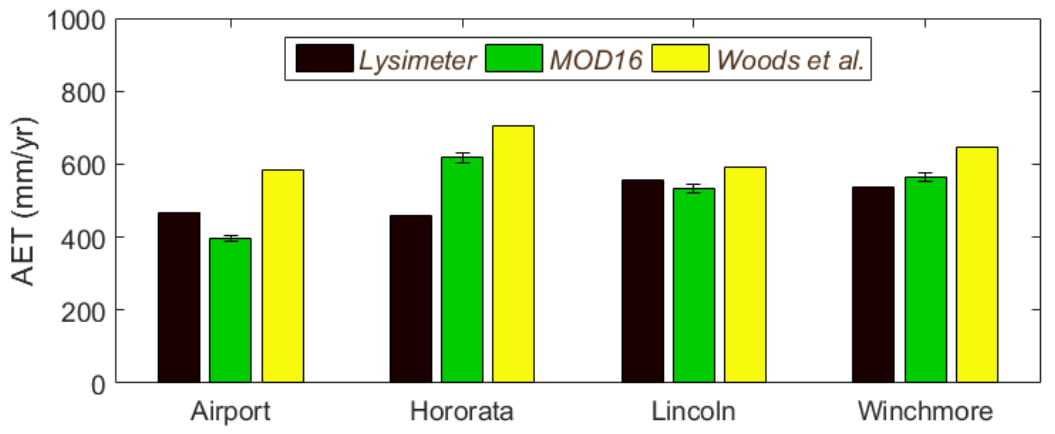

Figure 13. Mean annual AET derived from lysimeters in the Canterbury Plains, New Zealand, compared to MOD16 AET and AET from Woods et al. (2006). 


\section{References}

Ahnert, F.: Functional relationships between denudation, relief, and uplift in large, mid-latitude drainage basins, American Journal of Science, 268, 243-263, doi:10.2475/ajs.268.3.243, 1970.

Akbar, M., Petricola, M., Watfa, M., Badri, M., Charara, M., Boyd, A., Cassell, B., Nurmi, R., Delhomme, J.-P., Grace, M., Kenyon, B., and Roestenburg, J.: Classic Interpretation Problems: Evaluating Carbonates, Oilfield Review, 7, 38-57, 1995.

Alkhaier, F.: Land surface recharge calculations for the Waimakariri groundwater model, In review Report No. R16/10, Environment Canterbury Regional Council, 2016.

Bandaragoda, C., Tarboton, D. G., and Woods, R.: Application of TOPNET in the distributed model intercomparison project, Journal of Hydrology, 298, 178-201, doi:10.1016/j.jhydrol.2004.03.038, 2004.

Beck, H. E., van Dijk, A. I. J. M., Miralles, D. G., de Jeu, R. A. M., Sampurno Bruijnzeel, L. A., McVicar, T. R., and Schellekens, J.: Global patterns in base flow index and recession based on streamflow observations from 3394 catchments: Global Patterns in Base Flow Characteristics, Water Resources Research, 49, 7843-7863, doi:10.1002/2013WR013918, 2013.

Booker, D. and Woods, R.: Comparing and combining physically-based and empirically-based approaches for estimating the hydrology of ungauged catchments, Journal of Hydrology, 508, 227-239, doi:10.1016/j.jhydrol.2013.11.007, 2014.

Burberry, L., Moore, C., and Dumbleton, B.: Towards an improved understanding of the Knapdale aquifer: a modelling study of anomalous nitrate levels in the Knapdale groundwater zone., ESR Report Envirolink Grant 1206-ESRC254, ESR, 2013.

Calmels, D., Galy, A., Hovius, N., Bickle, M., West, A. J., Chen, M.-C., and Chapman, H.: Contribution of deep groundwater to the weathering budget in a rapidly eroding mountain belt, Taiwan, Earth and Planetary Science Letters, 303, 48-58, doi:10.1016/j.epsl.2010.12.032, 2011.

Cronshey, R.: Urban hydrology for small watersheds, Technical Report TR-55, 164p., US Dept. of Agriculture, Soil Conservation Service, Engineering Division, 1986.

DHI: MIKE 2016: MIKE SHE Integrated catchment modelling, http://www.mikepoweredbydhi.com/products/ mike-she, accessed April 2016, 2016.

Doherty, J.: PEST, Model-independent parameter estimation. User Manual Part I, Watermark Numerical Computing, 6 edn., 2016.

Döll, P. and Fiedler, K.: Global-scale modeling of groundwater recharge, Hydrology and Earth System Sciences, 12, 863-885, doi:10.5194/hess-12-863-2008, 2008.

Doyle, J. M., Gleeson, T., Manning, A. H., and Mayer, K. U.: Using noble gas tracers to constrain a groundwater flow model with recharge elevations: A novel approach for mountainous terrain, Water Resources Research, 51, 8094-8113, doi:10.1002/2015WR017274, 2015.

Fan, Y., Li, H., and Miguez-Macho, G.: Global Patterns of Groundwater Table Depth, Science, 339, 940—943, doi:10.1126/science.1229881, 2013.

Fitts, C. R.: Groundwater science, Academic Press, Amsterdam, 2 edn., 2013.

660 Freeze, R. and Cherry, J.: Groundwater, Prentice-Hall, Inc., Englewood Cliffs, NJ, 1979.

Geographx: Geographx New Zealand DEM 2.1, http://geographx.co.nz/_wp/wp-content/uploads/2012/12/ GX-Terrain-Metadata.pdf, accessed November 2015, 2012. 
Hydrol. Earth Syst. Sci. Discuss., doi:10.5194/hess-2016-410, 2016

Gleeson, T., Smith, L., Moosdorf, N., Hartmann, J., Dürr, H. H., Manning, A. H., van Beek, L. P. H., and Jellinek, A. M.: Mapping permeability over the surface of the Earth, Geophysical Research Letters, 38, doi:10.1029/2010GL045565, 102401, 2011.

GNS Science: QMAP, http://www.gns.cri.nz/Home/Our-Science/Earth-Science/Regional-Geology/ Geological-Maps/1-250-000-Geological-Map-of-New-Zealand-QMAP, accessed March 2014, 2012.

Hendriks, M. R.: Introduction to physical hydrology, Oxford University Press, Oxford, UK, 2010.

Hong, T. and White, P.: Rainfall recharge estimation based on a nonlinear Bayesian technique with a dynamic state-space formulation in the Canterbury Plains, GNS Science Report 2014/37, 44p, GNS Science, 2014.

Hou, A. Y., Kakar, R. K., Neeck, S., Azarbarzin, A. A., Kummerow, C. D., Kojima, M., Oki, R., Nakamura, K., and Iguchi, T.: The Global Precipitation Measurement Mission, Bulletin of the American Meteorological Society, 95, 701-722, doi:10.1175/BAMS-D-13-00164.1, 2014.

Landcare Research: LRIS portal, https://lris.scinfo.org.nz/p/about-lris-portal/, accessed March 2016, 2014.

Ministry for the Environment: A Guide to the National Policy Statement for Freshwater Management 2014, Ministry for the Environment New Zealand, publication number ME 1202, 2008.

Ministry for the Environment: Proposed National Environmental Standard on Ecological Flows and Water Levels: Discussion Document, http://www.mfe.govt.nz/publications/rma-fresh-water/ proposed-national-environmental-standard-ecological-flows-and-water, accessed July 2016, 2013.

Miralles, D. G., Holmes, T. R. H., De Jeu, R. A. M., Gash, J. H., Meesters, A. G. C. A., and Dolman, A. J.: Global land-surface evaporation estimated from satellite-based observations, Hydrology and Earth System Sciences, 15, 453—469, doi:10.5194/hess-15-453-2011, 2011.

$\mathrm{Mu}, \mathrm{Q} .$, Zhao, M., and Running, S.: Running, Improvements to a MODIS global terrestrial evapotranspiration algorithm, Remote Sensing of Environment, 115, 1781—1800, doi:10.1016/j.rse.2011.02.019, 2011.

Newsome, P., Wilde, R., and Willoughby, E.: Land Resource Information System Spatial Data Layers - Data Dictionary, 75p., Technical report, Landcare Research New Zealand Ltd, Palmerston North, New Zealand, 2008.

NIWA: January 2002 South Island and Waikato Flooding ( 2002-01-11 ), Historical Weather events report 200201-11, NIWA, hwe.niwa.co.nz/event/January_2002_South_Island_and_Waikato_flooding, accessed January 690 2016, 2002a.

NIWA: January 2002 New Zealand storm ( 2002-01-01 ), Historical Weather events report 2002-01-01, NIWA, hwe.niwa.co.nz/event/January_2002_New_Zealand_Storm, accessed January 2016, 2002b.

NTSG: MODIS Global Evapotranspiration Project (MOD16), http://www.ntsg.umt.edu/project/mod16, accessed January 2016, 2013.

695 Park, T.: Personal communication, phD student at Boston University, Department of Earth and Environment, Boston University, Cliveg Research Group, 2015.

Pozzi, W., Sheffield, J., Stefanski, R., Cripe, D., Pulwarty, R., Vogt, J. V., Heim, R. R., Brewer, M. J., Svoboda, M., Westerhoff, R., van Dijk, A. I. J. M., Lloyd-Hughes, B., Pappenberger, F., Werner, M., Dutra, E., Wetterhall, F., Wagner, W., Schubert, S., Mo, K., Nicholson, M., Bettio, L., Nunez, L., van Beek, R., Bierkens, M., de Goncalves, L. G. G., de Mattos, J. G. Z., and Lawford, R.: Toward Global Drought Early Warning Capability: Expanding International Cooperation for the Development of a Framework for Monitoring 
and Forecasting, Bulletin of the American Meteorological Society, 94, 776-785, doi:10.1175/BAMS-D-1100176.1, 2013.

Rawlinson, Z., Westerhoff, R., White, P., Schaller, K., and Moore, C.: Estimation of Rainfall Recharge to Groundwater in the Waipa River Catchment from three independent models, GNS Science Consultancy Report 2015/212, 88p., GNS Science, 2015.

Rushton, K., Eilers, V., and Carter, R.: Improved soil moisture balance methodology for recharge estimation, Journal of Hydrology, 318, 379-399, doi:10.1016/j.jhydrol.2005.06.022, 2006.

Samanta, A., Costa, M. H., Nunes, E. L., Vieira, S. A., Xu, L., and Myneni, R. B.: Comment on "DroughtInduced Reduction in Global Terrestrial Net Primary Production from 2000 Through 2009", Science, 333, 1093-1093, doi:10.1126/science.1199048, 2011.

Scott, D.: Groundwater Allocation Limits: land-based recharge estimates, Tech. Rep. Environment Canterbury U04/97, 39p., Environment Canterbury, 2004.

Sims, A., Cox, S., Fitzsimmons, S., and Holland, P.: Seasonal infiltration and groundwater movement in schist bedrock, Southern Alps, New Zealand., Journal of Hydrology (NZ), 54, 33-52, 2015.

Smith, K. A. and Mullins, C. E., eds.: Soil and environmental analysis: physical methods, Books in soils, plants, and the environment, M. Dekker, New York, 2nd ed., rev. and expanded edn., 2001.

Summerfield, M. A. and Hulton, N. J.: Natural controls of fluvial denudation rates in major world drainage basins, Journal of Geophysical Research, 99, 13 871-13 883, doi:10.1029/94JB00715, 1994.

Tait, A.: Personal communication, principal Scientist at the National Climate Centre, NIWA, 2014.

Tait, A., Henderson, R., Turner, R., and Zheng, X.: Thin plate smoothing spline interpolation of daily rainfall for New Zealand using a climatological rainfall surface, International Journal of Climatology, 26, 2097-2115, doi:10.1002/joc.1350, 2006.

Tellinghuisen, J.: Statistical Error Propagation, The Journal of Physical Chemistry A, 105, 3917-3921, doi:10.1021/jp003484u, 2001.

Tschritter, C., Cameron, S., and White, P.: Incorporation of hydraulic properties in three-dimensional geological models, GNS Science Report 2013/53, 26p., GNS Science, 2014.

USGS, Global Land Cover Facility, U.: Shuttle Radar Topography Mission (SRTM), unfilled finished version B., http://www.landcover.org, accessed March 2014, 2006.

Wada, Y., van Beek, L. P. H., van Kempen, C. M., Reckman, J. W. T. M., Vasak, S., and Bierkens, M. F. P.: Global depletion of groundwater resources, Geophysical Research Letters, 37, 1-5, doi:10.1029/2010GL044571, 2010.

Ward, P. J., Jongman, B., Salamon, P., Simpson, A., Bates, P., De Groeve, T., Muis, S., de Perez, E. C., Rudari, R., Trigg, M. A., and Winsemius, H. C.: Usefulness and limitations of global flood risk models, Nature Climate Change, 5, 712-715, doi:10.1038/nclimate2742, 2015.

Westenbroek, S., Kelson, V., Dripps, W., Hunt, R., and Bradbury, K.: SWB - A Modified Thornthwaite-Mather Soil-Water-Balance Code for Estimating Groundwater Recharge, Tech. Rep. U.S. Geological Survey Techniques and Methods 6-A31, 60 p., USGS, 2010.

Westerhoff, R.: Using uncertainty of Penman and Penman-Monteith methods in combined satel740 lite and ground-based evapotranspiration estimates, Remote Sensing of Environment, 169, 102-112, doi:10.1016/j.rse.2015.07.021, 2015. 
Hydrol. Earth Syst. Sci. Discuss., doi:10.5194/hess-2016-410, 2016

Manuscript under review for journal Hydrol. Earth Syst. Sci.

Published: 30 August 2016

(c) Author(s) 2016. CC-BY 3.0 License.

Westerhoff, R., Kleuskens, M., Winsemius, H., Huizinga, H., Brakenridge, G., and Bishop, C.: Automated global water mapping based on wide-swath orbital synthetic-aperture radar, Hydrology and Earth System Sciences, 17, 651--663, doi:10.5194/hess-17-651-2013, 2013.

White, P.: Snow storms in Canterbury and recharge to groundwater., GNS Science Consultancy Report 2007/87, 46p., GNS Science, 2007.

White, P., Hong, Y.-S., Murray, D., Scott, D., and Thorpe, H.: Evaluation of regional models of rainfall recharge to groundwater by comparison with lysimeter measurements, Canterbury, New Zealand., Journal of Hydrology (NZ), 42, 39—64, 2003.

White, P., Moreau-Fournier, M., Thorpe, H., and Lovett, A.: Summary of rainfall recharge measurements with lysimeters and ground-level rainfall observations 1952-1978 and 1997-2011, Canterbury, GNS Science Report 2013/10. 31p+CD., GNS Science, 2014.

Woods, R., Hendrikx, J., Henderson, R., and Tait, A.: Estimating mean flow of New Zealand rivers, Journal of Hydrology (NZ), 45, 95-110, 2006.

Yang, J., McMillan, H., Zammit, C., and Horrel, G.: Modelling Surface water - groundwater interaction in New Zealand: Model development and application, in: EGU Geophysical Research Abstract, vol. 17, pp. EGU2015-7450, Vienna, 2015.

Zhou, M., Ishidaira, H., Hapuarachchi, H., Magome, J., Kiem, A., and Takeuchi, K.: Estimating potential evapotranspiration using Shuttleworth-Wallace model and NOAA-AVHRR NDVI data to feed a distributed hydrological model over the Mekong River basin, Journal of Hydrology, 327, 151-173, doi:10.1016/j.jhydrol.2005.11.013, 2006. 